\title{
Translating Imperial Practices, Knowledge, and Taste Across the Mediterranean: Giulio Ferrario and Ignatius Mouradgea d'Ohsson
}

\author{
Giulia Calvi
}

In recent years, historiography on consumption, luxury, and fashion in the $17^{\text {th }}$ and 18 th centuries ${ }^{1}$ has focused on the exportation of luxury goods from Asia to northwestern Europe, especially to England and the Netherlands. Stimulating imagination and desire, these products were emulated among a widening sphere of consumers. From the late 17th century onwards, they were gradually integrated into a middle-class market of locally produced imitations and ultimately shaped new practices of middle-class gentility, femininity, and masculinity. Taste, demand, and fashion define "modern materiality" and situate "things" in the current historiographical account of the making of Europe since the Renaissance. ${ }^{2}$

Considering northwestern Europe as a "category",3 which leaves large parts of Europe and non-western societies out of the picture, this historiography draws a connection between affluence, women's capacity to increase

1 Maxine Berg (ed.), Goods from the East, 1600-180o (New York: 2015); Jan De Vries, "Understanding Eurasian Trade in the Era of the Trading Companies", in Maxine Berg (ed.), Goods from the East (New York: 2015): 7-39; Beverly Lemire and Giorgio Riello, "East \& West: Textiles and Fashion in Early Modern Europe”, Journal of Social History, 41 (2008): 887-916; Maxine Berg, "Luxury, the Luxury Trades, and the Roots of Industrial Growth: A Global Perspective", in Frank Trentmann (ed.), The Oxford Handbook of the History of Consumption, (www.oxfordhandbooks.com: 2012), 1-15.

2 Chandra Mukerji, From Graven Images: Patterns of Modern Materialism (New York: 1983); Lisa Jardine and Jerry Brotton, Global Interests, Renaissance Art Between East and West (London: 200o); Daniela Bleichmar and Peter C. Mancall (eds.), Collecting Across Cultures (Philadelphia: 2011); Dana Leibsohn and Jeanette Favrot Peterson (eds.), Seeing Across Cultures in the Early Modern World (London, 2012); Ulinka Rublack, Dressing Up. Cultural Identity in Renaissance Europe (Oxford: 2010); Paula Findlen, Early Modern Things (London: 2013); Mike Savage, "Status, Lifestyle and Taste", in The Oxford Handbook of the History of Consumption, (www .oxfordhandbooks.com: 2012), 1-13.

3 Jos Gommans, "For the Home and the Body: Dutch and Indian Ways of Early Modern Consumption", in Goods from the East, 331-349. 
household production, confessionalization and democracy. However, questions arising from globalization, as well as developments in the field of global studies, encourage a broadening of the boundaries that set the study of luxury consumption within new East-West and global connections. Many of the essays in this volume outline the emergence of cross-cultural practices as a distinctive feature, encouraging social change shaped by ethnicity, religion, class, and gender relations. In the 18th century, transregional contacts and exchanges influenced trade, consumption and print, architecture, interior decoration, food and modes of dress, and ways of collecting and displaying, as well as practices of self-fashioning. Recent research situates the expansion of sub-imperial élites and mercantile bourgeoisies in the context of commercial global capitalism, arguing for the growth of cultural patronage attracted to a transregional and transcontinental circulation of objects and technology across imperial boundaries. This, in turn, stimulated exchanges and stylistic eclecticism both in Europe and the Ottoman Empire.

In recent years, some historians have begun to discuss the possibility of an Ottoman consumer revolution. Extant primary sources, however, do not allow scholars to answer basic questions regarding new consumption patterns comparable to the Industrious Revolution model proposed for early modern northwestern Europe. Moving away from this paradigm, Suraiya Faroqhi emphasizes the growth of an Ottoman middle-range market of semi-luxury goods protected from foreign imports, which compensated for the decline of old luxury consumption in the 18th century. ${ }^{4}$ The importance of an Asian circulation of luxury goods and styles sheds light on exchanges between the Ottoman Empire, Persia and India, and on processes of imitation and cheap local production for urban consumption and export which predate European colonial expansion. Focusing on the circulation of people, goods and knowledge across the Mediterranean also means looking at practices of mediation, translation and networking, as well as at letters, travelogues and images, all of which point to the experience of moving across borders and to the self-fashioning practices of moving subjects.

This chapter focuses on transfers of knowledge, looking at the authors, books, and woodcut prints circulating between Istanbul, Paris and Milan at

4 James Grehan, Everyday Life and Consumer Culture in 18th-Century Damascus. (London: 2007); Suraiya Faroqhi, "Decline and Revivals in Textile Production" in Suraiya Faroqhi (ed.), The Cambridge History of Turkey, (Cambridge: 2016), 374 http://dx.doi.org/10.1017/ CHOL9780521620956.017. Nebahat Avcioglu and Finbarr Barry Flood, "Introduction, Globalizing Cultures: Art and Mobility in the Eighteenth Century" Ars Orientalis, 39, (2010): $7-38$. 
that time. Following the Renaissance, books, maps and prints were regarded as objects of luxury consumption, amassing in the private collections of the literate European élite and the courts. In the 18th century, a growing desire for knowledge of "others", not only in Europe but also in non-western countries such as East Asia and the Ottoman Empire, expanded the production and circulation of books and prints among a growing readership. In Istanbul, in 1727, during the reign of Ahmed III, the Hungarian convert Ibrahim Müteferriká established an Ottoman language printing press where he published the Tarih$i$-Hind, a history of the Americas based on the 16th century Italian translation of Historia de las Indias by the Spanish historian Francisco Lopez de Gomara. Published in 1730, the volume included twelve woodcut prints picturing the flora and fauna of the Americas. ${ }^{5}$ While Müteferrikás printing press aimed to translate European works for local consumption, Ottoman intellectuals began to describe the structure of the Ottoman Empire for a European audience. Ignatius Mouradgea d'Ohsson (1740-1807) was the first Ottoman to publish, in French, a three-volume illustrated history of the Ottoman Empire $(1787,1790$, 1820). I will focus on the circulation of this work between Istanbul, Paris and Milan where, Giulio Ferrario (1767-1849) used it as his main textual and visual reference in his encyclopedic Il costume antico e moderno (1817-1834). The two authors have never been studied in connection to one another and this analytical angle sheds light on the cultural transfer and translating capacities of mediators, such as Ferrario and Mouradgea d'Ohsson, who worked across imperial boundaries in different geopolitical centres of the Mediterranean.

My point of entry into the work of both authors is Ottoman material culture and the growing fashion for Kashmir schals in Istanbul in the second half of the 18th century. Focusing on the social practices of Ottoman civil society as described, analyzed and pictured by both authors, I shall reconstruct the interconnections between both texts and the images that accompany them, in the context of the circulation of knowledge, books and prints across the Mediterranean world.

\section{Religious Minorities and the Limits of Fashion}

The following text comments on modern Ottoman civil society, where luxury textiles coming from the East encouraged practices of social distinction and

5 Thomas D. Goodrich, The Ottoman Turks and the New World: A Study of Tarih-i Hind-i Garbi and Sixteenth-Century Ottoman Americana (Wiesbaden: 1990). 
the creation of different markets for the elites and ordinary people. In the context of consumption, these markets transgressed religious norms:

Under Ottoman rule a widespread deviation from the traditional clothing norms of the Quran took place. With the exception of the Ulema and a few lay devotees, all well-to-do families manage to procure silk clothes and the richest textiles. Those coming from India are the most sought after. They come in single colors, striped, with flowers and in every kind of silk, in golden and silver thread for the gentle sex, for servants in wealthy households, and for some administrators at the court. Schals of extremely fine wool and highly priced are in great fashion. Price is of no concern, as the Ottomans love to have those measuring twelve feet by four and of such fine weave that they can pass through a ring. Men and women wear them all year long: in winter, men wear them to walk the streets and go horse riding. They cover their heads with these shawls in bad weather, as in those countries people have no umbrellas and carriages are reserved for the delicate sex. Women cover their heads and shoulders and some make winter clothes that cost more than the finest muslins and the more exquisitely embroidered textiles. People of the lower orders wear locally produced schals. ${ }^{6}$

This detailed description of the inclination for precious Indian textiles and Kashmir shawls in Istanbul contrasts with the practices of less wealthy Christian minorities in provincial towns who follow the dictates of Ottoman and western fashion in a more flexible way:

Christian women, especially the Greeks, enjoy more freedom and sometimes follow European fashions and use makeup. If they leave the house, they have to conform to Muslim rules and wear the veil, a dark feredjé and black shoes. All women from other nationalities have to follow the same rules, and in all urban districts police officers from time to time read out loud these sumptuary regulations. Such rigid dressing codes are not enforced in the provinces, and in the islands of the Greek archipelago there is the greatest freedom. Here women keep to their ancient customs and go unveiled. This is why European women that have settled in the

6 Giulio Ferrario, Il costume antico e moderno, o storia della milizia, della religione, delle arti, scienze ed usanze di tutti i popoli antichi e moderni, provata coi monumenti dell'antichità e rappresentata cogli analoghi disegni. Dell'Impero Ottomano. Degli Slavi moderni a cura di Carlo Magnetti, Europa, vol. 4 (Milano: 1827), 385 (my translation). 
provinces of the Empire are less restless. Their clothing is indeed a bizarre mixture of many costumes: some wear the feredjé and an Indian schal in lieu of a veil. ${ }^{7}$

Both quotes introduce the reader to crucial features regarding the social use of luxury goods whose main rhetorical and social use was embedded in a web of values and norms. Religion, ethnicity, class and gender affected the level of demand both of locally produced and imported goods, constructing the social codes that defined consumption, sociality, and appearance. In order to acquire them, wealthy Muslim families broke the monopoly of Quran legislation and adopted transgressive clothing practices: elite men and women wore original textiles imported from India, while ordinary people bought locally produced imitations. The rigid sumptuary codes in Istanbul contrasted with the more tolerant milieu of provincial towns: religion was a central tenet in the construction of consuming practices for both Muslims and Christians. Thus, fashion and the law, both forms of "specialized knowledge" for acquiring goods with "high discriminatory value", regulate consumption. ${ }^{8}$

\section{Giulio Ferrario, Il costume antico e moderno (1817-1834)}

The previous quotes come from Giulio Ferrario's L'Impero Ottomano, the fourth of his nine volumes on Europe in his monumental collection of world history, Il costume antico e moderno. It was printed in Milan in 21 volumes between 1817 and 1834, in parallel Italian and French editions.

Born in Milan in 1767 , Ferrario was an erudite ecclesiastic charged with the direction of the Biblioteca Braidense, the main public library in the city. ${ }^{9}$ The historical context in which Il costume antico e moderno is situated is that of the aftermath of the French Revolution, the formation of Napoleon's Empire, and the Habsburg takeover of parts of it, namely the kingdom of Italy and of Illyria, within the transformations affecting the Ottoman Empire and its European regions due to the Russian Empire's aggressive military policy. Ferrario lived through Napoleon's reign in Italy, including its demise in 1814. He then became a faithful subject of the Austrian monarchy and dedicated his major work to the Habsburg Emperor Francis I. He died in Milan in 1847.

7 Ferrario, Il costume, 358.

8 Arjun Appadurai, "Introduction: Commodities and the Politics of Value", in Arjun Appadurai (ed.), The Social Life of Things. Commodities in Cultural Perspective (Cambridge: 1986), 38.

9 Dizionario Biografico degli Italiani, ad vocem. 
A sophisticated philologist and cultural entrepreneur, Ferrario used his intellectual activity and public persona to acquire a meaningful position in the urban cultural milieu of Milan, the capital of the kingdom of Italy under Napoleon Bonaparte. In 1802, he became part of the staff and then, in 1838, director of the Biblioteca Braidense, the main public library of the city. Charged with different responsibilities in this lieu du savoir for over forty years, Ferrario used the extensive and rare collections of the library to gather a group of scholars and artists around his initiatives. These contemporaries shared similar cultural and aesthetic concerns, and contributed to the first major collection of Italian literary classics (1802-1814) in 242 volumes. The Library was-and still is-part of an institutional complex comprising the Accademia and Pinacoteca of Brera where the leading artists of the day were trained and many prints in Il costume antico e moderno were produced.

Ferrario's stable institutional position did not change after the demise of Napoleon's rule in 1814 and the return of the Habsburgs. Never a supporter of Bonaparte, he quickly aligned himself with the new régime and continued to be proactive in many fields of knowledge. He expressed his passion for theatre and opera in a multivolume work on ancient and modern Italian theatres (1830); founded and directed I Teatri, a periodical where he wrote on music and choreography; and edited Il costume antico e moderno (1817-1834), a collection aimed at popularizing knowledge of exotic and foreign cultures in an encyclopedic format using a blend of erudition and entertainment. Acknowledging the support of many public and private libraries, scholars, scientists, and art collectors, Ferrario expounds his methodology: "We have concentrated in a single work sources that were disseminated in rare and extremely expensive volumes, for our young students to benefit from [...] we hope that the fine arts will also profit from our work, as artists will no longer have to search in vain for the ideal costumes."10

He makes it clear from the start that the collection selects, gathers and translates rare sources from a variety of authors, making them affordable and available to the literate readership. Nowhere is there any reference to personal experience, travel or direct observation: within a long-standing Italian tradition dating from the Renaissance, Il costume antico e moderno is situated within the increasingly popular field of world history and armchair travel literature.

A group of Milanese artists, many of whom came from the Academy of Brera, designed and engraved the hand-coloured prints in each volume, "representing figures that have been diligently researched in the best histories of statues, coins, and bas-reliefs, as well as from the most trustworthy travelogues" and 
not from their own fancy. ${ }^{11}$ Some of them, notably Appiani and Gallina, were active in the restyling of Milan as the new capital of the Italian kingdom under Napoleon. Coordinated by Ferrario, who authored many volumes and printed the whole collection, the monumental work was a group enterprise with the institutional backing of the Biblioteca Braidense and the art academy of Brera, in which colleagues (such as the former director of the Biblioteca), artists, and collaborators participated. This work became a model of erudite compilation in the 19th century and was reprinted seven times before the 1840s, including, most notably, a cheap in quarto edition put on the market in Florence in 1823 .

Funding for the project was obtained through public subscription. Emperor Francis I, whose name was followed by thirteen members of the European royalty and high nobility, opened the list of the 211 so-called associates. The catalogue of associates provides useful information about the distribution of copies across Europe: all customers could choose hand-coloured or black-andwhite editions. Subscriptions were made by numerous public libraries in Italy, as well as in cities such as Berlin, Leipzig, London, Mannheim, Munich, Paris, St. Petersburg, and Vienna. Among individual subscribers, there were book sellers, printers, merchants, traders, producers of painted cloth, painters, engravers, professionals (engineers, architects, and lawyers), state employees and ecclesiastics.

Ferrario's 21-volume work builds upon the tradition of early modern costume books in a world perspective, printed in Europe and in some nonwestern countries. Within this long-standing tradition, in early 19th-century Milan, this encyclopedic work was also part of a developing editorial production in which compendiums of contemporary travel literature gained increasing success. Fuelled by a publishing business keen on establishing a canon of modern travel literature of the last fifty years, Ferrario's work uses diaries, travelogues, and letters, some with sketches and watercolours, that had not been selected, edited, and translated before. ${ }^{2}$

The volume on the Ottoman Empire is the fourth of nine books on Europe of which two, in the wake of Philhellenism, are dedicated to Greece. The first

11 Ferrario, Il costume, 1 , XXIV.

12 Some French compendiums provided an initial but outmoded model, such as the “Annales des voyages" edited by Malte Brun (1807), among the often quoted sources of Ferrario's Ottoman Empire volume. Consulting Boucher de la Richarderie's bibliographical index but especially translating what was newly published in England and France, between the 1820 s and 1830 s Sonzogno published the 144 volumes of his "Raccolta de viaggiatori”. Marino Berengo, Intellettuali e librai nella Milano della Restaurazione (Milano: 2012 repr. Milano: 1980). 
part of the volume provides a rather factual synthesis of the history of the Ottoman Empire from its initial stages up to the present day, probably drawn from some popular compendiums circulating in Italy ${ }^{13}$ the second part offers an ethnographic overview of civil society ("civil customs", the customs of "private people") outlining the practices that promote and regulate taste formation. The book's last section is dedicated to the "modern Slavs" and is largely based on the Venetian abbé Fortis's classic journey across Dalmatia (1774), Cassas's Voyage picturesque et historique (1802), on Pouqueville's Voyages (1805), and on the Carniolan physician Balthazar Hacquet's L'Illyrie et la Dalmatie, including his ethnographic observations of the southern Slavs translated from German into French (1815). ${ }^{14}$ The peculiar orientalizing gaze in the work of these authors projects a fascination with manliness and primitivism that Maria Todorova labelled balkanism..$^{15}$ The term has become a synonym for the reversion to the tribal, the backward, the primitive, and the barbarian; consumption as a discourse and a practice does not belong to this simple and violent society. Therefore, that section will not be discussed further in this chapter.

Focusing on the social practices of Ottoman civil society, I shall reconstruct the circulation of texts that shaped the narrative in Il costume antico e moderno. The abbé Carlo Magnetti, one of Ferrario's collaborators, edited the volume, which has important lacunae: no bibliography and hardly any footnotes. References to sources are fragmented and lack authors' names, therefore correct or full titles of works are difficult to identify. In order to elucidate the overall cultural framework in which the volume is set, it is particularly important to trace this web of references, to find the original sources that went into both the text and the hand-coloured prints, and to identify the artists-designers, painters, and engravers - who decorated the work. Reconstructing the complexity of this endeavour means understanding not only cultural practices and transfers of knowledge, but also the crucial role of transcultural mediation that authors and texts performed between Italy and the Ottoman world.

13 Giovan Battista Rampoldi's Annali Musulmani published (Milan: 1822-26) is essentially a compilation modelled on Barthélemy d'Herbelot de Molainville's Bibliothèque Orientale (1777-1779).

14 Larry Wolff, Venice and the Slavs: The Discovery of Dalmatia in the Age of Enlightenment (Stanford: 2002); Francois Charles Pouqueville, Voyage en Morée, à Constantinople et en Albanie 1798, 1799, 1800, 1801 (Paris: 1805); Marie-Gabriel de Choiseul-Gouffier, Voyage pictoresque de la Grèce, 1-3 (Paris: 1782, 1809, 1822); Louis-François Cassas, Voyage pittoresque de la Syrie et de l'Egypte (Paris: 1799); Balthasar de la Motte Hacquet, L'Illyrie et la Dalmatie ou Moeurs, usages et costumes de leurs habitants (Paris: 1815).

15 Maria Todorova, Imagining the Balkans (Oxford: 1997). 


\section{Turbans, Shoes, Kashmir and Fur}

The new inclination for long and light Kashmir schals, imported from India to Istanbul for the wealthy and produced locally for middle-range consumers, traces a fil rouge connecting material modernity, distinction, and taste. "Positional goods", whose value depends both on their social and cultural meaning and on how they compare with things owned by others, construct hierarchies of status. ${ }^{16}$ Practices, objects, interior decoration and food are signified within a set of social markers as well as by their western and eastern origins. In Il costume antico e moderno, practices involving coffee and tobacco are described in the opening section on civil customs. Christian and Muslims alike drink coffee, while women and men smoke tobacco introduced to Constantinople by foreign merchants. The wealthy use silver and golden pipes decorated with precious stones while the people smoke clay pipes or the narguile of Persian origin. Recently, the chewing of tobacco-unheard of among the Ottomanshas started to spread among the elites who enjoy a locally grown variety called rapé. Foreign tobacco powder is considered worthless, except tobacco from Corfu, which the Venetians used to trade on a large scale. Strictly regulated by Islamic law in the past, coffee, tobacco, and opium started to be consumed by all kinds of people, including the sultan himself:

A variety of opiates is now in fashion and especially the berdjh madjounn. The simple madjounn is made with poppies or aloe and different kinds of spices, while the most refined kind contains grey amber, cochineal, moss and other precious essences. The Sultan and the high-ranking officials of the Empire add crushed fine pearls, rubies, emeralds and corals and because of these stones, it is called djewahir-madjounny. A small jar is worth at least one thousand lire. ${ }^{17}$

Depending on status, individuals carry pills of opium in golden, silver, tortoise, or cardboard snuff boxes.

Women prefer small bites of electuaries without opium, but with moss, which smells nice and goes well with coffee. Women also enjoy chewing mastic, an aromatic resin from lentiscus, which grows in the islands of the Greek Archipelago, especially in Chios. The Ottomans adopted from the Arabs a great love of perfume that a strict etiquette prescribes and regulates for the

16 Fred Hirsch, The Social Limits to Growth (London: 1977).

17 Ferrario, Il costume antico e moderno, Impero Ottomano, 344. 
ministers and officials in court. Guests and foreign ambassadors were greeted with a ceremonial offer of coffee, tobacco, and perfume..$^{18}$

As far as clothing is concerned, consumption and fashion cannot eschew sumptuary legislation obeying religious tenets. Ferrario's text articulates this tension between religious legislation and luxury with a keen focus on men's clothing, particularly on the turban as the main distinguishing feature of ethnicity and religious belief. Clothing also embodies political meanings and wearing a Persian beret or a European hat unleashes violent reactions, especially in times of popular uprisings in the Empire. Overall, the main rule for the Ottomans, according to Ferrario, is to show neither pomp nor negligence. They are allowed a discrete elegance, which they consider as a homage offered to the Lord, except on Fridays and during the feast of Beyram. They can wear black and white, but not red and yellow. Gold and silver cloth is prohibited. Luxury among the Ottomans is confined to the "old luxury"19 of the court:

[Osman I] was the first to introduce in the Palace the luxury and magnificence of Asian courts [...] and Suleyman I increased magnificence up to a point that nobody had seen before him. Notwithstanding the changes that luxury required, Ottomans both in the capital and the provinces of the Empire always kept the long dress of Orientals, altering the shape and cut and especially the shape and ornaments on their turbans. ${ }^{20}$

Suleyman also started the fashion for turbans and clothes that distinguish the different orders and ranks of the state apparatus:

and thousands of workshops opened where crowds of workers incessantly produced and decorated turbans. The inhabitants of Constantinople and those of the European provinces usually wear turbans of white muslin. Those living in Syria, the Arabs and Egyptians use a striped cloth or a simple colored one. The same fashion applies to people living in Bursa, Caramania, Adana, Bosnia and Albania. The non-Muslim subjects are immediately visible as their headgear is very different. They are only allowed to wear a high sheepskin black busby called calpach or to cover their head with a piece of dark cloth. The Greek inhabitants of the Archipelago wear

18 Ferrario, Impero Ottomano, 345-346.

19 Maria Giuseppina Muzzarelli and Carla Campanini (eds.), Disciplinare il lusso (Bologna: 2003); Jan De Vries, The Industrious Revolution (Cambridge: 2008); Peter Mc Neil and Giorgio Riello, Luxury (Oxford: 2016). 
a red or white woolen beret. A Muslim should never dress in a foreign fashion; a dress, and more so, headgear that does not conform to native custom would cover him with shame and opprobrium and would yield to a suspicion of apostasy. The worst thing he could do would be to wear a Persian beret or a European hat. They hate hats to such an extent that once, during the troubles that threatened the Empire, they used the trick of nailing a hat to the door of a minister, or a high ranking official that the rebels had sworn to kill as a traitor of his native land or deserter of his religion. ${ }^{21}$

Further distinguishing features are shoes: of yellow Moroccan leather for Muslims, and dark blue for ulemas, while non-Muslim subjects were required to wear black ones. Europeans entitled to wear Muslim dress were permitted to have yellow shoes, but could not wear a turban, a distinguishing feature of the dominant nation. They were, instead, obliged to wear a beret of marten or sable fur. European travellers dressed in oriental clothes could risk wearing a turban, but, if spotted, might experience some hostility. This was often the case in the Ottoman lands where people were too proud of their own dress to allow others to use it. In these situations, the best solution would be to wear a tartar beret. In spite of its green colour, it was less liable to provoke prejudice. Foreign ambassadors could never uncover their heads as Muslims found it indecent. During Ferrario's days, all Muslims shaved their head and wore a small red beret, called a fez, with the turban placed on top. Men cut their hair off to avoid appearing effeminate.

As we observed earlier, Kashmir schals typify modern luxury. Their exquisite texture rivals the finest muslin and embroidered textiles, thus reducing silk consumption. Furs are another example of luxury goods that confer social distinction. As the supreme tastemaker, Sultan Muhammed II introduced furs to Constantinople and decided what was fashionable and how furs should be used. Widespread consumption of fur at all levels of society followed the fall of Constantinople:

In winter the artisan, the soldier, the peasant want one of lamb, mutton, cat or squirrel. The urban dweller is happy with fox and hare; the rich and the Great have a wardrobe stacked with sable, marten, white fox, ermine and miniver. A strict etiquette requires all these varieties, as in autumn one needs an ermine dress, three weeks later one of miniver, and sable all winter long. In summer, one wears a large dress—-the feredjé-with a 
lining of camel or goat wool. Changing clothes depends on the Sultan's will. Black fox is reserved for His Imperial Highness. Women are much freer to use fur, as only money and taste decide what they can wear. Therefore, in winter they show the most beautiful fur coats and adorn their dresses with a border of fur around the skirt. A proverb says that it is expensive to dress a woman, but it is incomparably more so to dress an Ottoman lady. The smallest fur item costs between 1200 and 1500 lire. In the midst of winter, rich people and high-ranking court officials wear two or three fur coats. The climate is not so rigid, but houses have many windows and are built for warm weather and there are no fireplaces, nor warming pans for beds and therefore furs are necessary. ${ }^{22}$

Ferrario argues that this indulgent attitude towards women's attire is a compensation "for the subordinate position they have to bear".23 Married women have "a master rather than a husband and they cannot see any other men except peeping through a hole in their window blinds." ${ }^{24}$

If the financial status of the family can afford it, women are adorned with gold and precious stones and their "high headsets remind us of a bouf which was fashionable in Europe thirty-five years ago". ${ }^{25}$ The text addresses European readers by reminding them of their own past fashions, and by evoking a variety of headgear to help them visualize Ottoman women's dress. Another analogy drawn between stone garlands and fans aims to domesticate gestures and attitudes between East and West: "They hold a garland of jasper and agate to play with and show off; just as in Europe they use fans." ${ }^{26}$ Whereas in Europe fans are part of women's attire and are used in public, in Ottoman society men and women use fans mostly in private. Round and made from peacock feathers or parchment, fans are decorated with golden flowers and have ivory or ebony handles. Men have plain ones. Servants and slaves fan their masters and waft flyswatters in front of the sultan and his ministers.

These analogies between Europe and the Ottoman Empire set the stage for Ferrario's main question concerning fashion, consumption, and change that intersects well-known moral and aesthetic tensions:

$\begin{array}{ll}22 & \text { Ibid., 351. } \\ 23 & \text { Ibid., 353. } \\ 24 & \text { Ibid., 356. } \\ 25 & \text { Ibid., 354. } \\ 26 & \text { Ibid., 354. }\end{array}$


This constant lack of stability that incessantly transforms European women's clothing does not rule in the Orient. Headgears, cuts, cloth are more or less always the same. Why? Because there are no merchants of fashion who tease ambition with a constant variety of inventions. While Muslim women follow a uniform style and lack the elegance and loveliness of European women, they compensate for these advantages with a noble custom and the simple graces of nature. ${ }^{27}$

This echoes Lady Mary Wortley Montagu's comments on Ottoman women's natural waistlines, which contrasted with the tight bodices and makeup favoured by western women to hide the ravages of time and personal passions. Veiled foreheads and eyebrows which met in the middle were the more modest indicators of Ottoman sophistication. Slaves did not cover their foreheads, or wear a veil, or furs. They also wore a small white or red beret imported from Orléans in France under their outer headgear.

\section{Contact Zones and Trans-Imperial Subjects}

As we have already mentioned, non-Muslim women, especially Greeks, enjoy greater freedom and can follow European dress styles in private. Greek homes are spaces where interethnic sociality is encouraged and where Europeans meet and mix with local minorities who entertain with music and dance:

Beyond the romeca that girls are taught to dance at home, in Greek households a foreigner will admire the French, English, and German contredances. These entertainments however cannot be compared to the loud parties and dances that in the big European cities take place in theaters and in rich homes. Foreign ministers and wealthy merchants living in the Empire try as best they can to throw parties that somehow resemble European ones. Europeans in these cities move to the same districts, and in Pera they are in close contact with Muslims and live as they would in the freer cities inviting whole Greek families with men and women to dance together. ${ }^{28}$

27 Ibid., 354-355.

28 Ibid., 370-71. 
The Lettres of Madame de Chenier are an interesting source on Greek dances and the ways in which mothers taught their daughters to dance at home. ${ }^{29}$ Née Elisabeth Lomaca, Madame de Chenier was born in Constantinople, in 1729. Her father, Santi Lomaca, a Greek dragoman (interpreter) at the court of Sultan Ahmed III, was one of the envoys in the diplomatic mission to France in 1722-23. Elisabeth Lomaca received a cosmopolitan education and grew up in the international milieu of the city, speaking Greek, Ottoman Turkish, and French. ${ }^{30}$ As the daughter of the sultan's interpreter, her training and upbringing in a context of cultural and linguistic mediation turn her into a transimperial subject, ${ }^{31}$ i.e. an intermediary belonging to an ethnic minority that articulates and is, in turn, shaped by the making and shifting of boundaries between East and West and across empires in the Mediterranean world.

Santi Lomaca's home would probably have hosted cosmopolitan gatherings similar to those described previously in Ferrario's quote about musical entertainments. Such places served as "contact zones", where men and women, Greeks and Europeans, danced the French, English, and German contredances, in spite of Ottoman legislation prohibiting music and dance. Translator, trader and, diplomatic agent, Santi Lomaca negotiated practices of mediation in the social world of 18 th-century Constantinople where music and dance shaped contacts and exchanges. In his daughter, Elisabeth's Lettres, framed in the wake of Philhellenism, dance becomes a medium to represent her love for antiquity, her nostalgia, and feelings of disempowerment and expropriation. She writes that Turks reserved, for their own amusement and for the women they segregated, the Ionian dance "that one can still see today in Smyrna and in Asia Minor where the taste for lascivious dancing lingers on. They enjoy to have these lascivious and voluptuous dances performed before them". ${ }^{32}$ Dances that commemorate the past of a free nation are now staged in front of rulers who segregate women.

29 Madame de Chénier, Lettres grecques (Paris: 1879), 139, 155.

30 She married Chénier, a French diplomat in Istanbul, and was the mother of André Chenier, the poet that Robespierre sentenced to death during the French Revolution. Later in life, Elisabeth Lomaca moved to Paris and died there.

31 The term is used in Nathalie Rothman, Brokering Empire. Trans-Imperial Subjects between Venice and Istanbul (Ithaca: 2012); see also Mary Louise Pratt, Imperial Eyes. Travel Writing and Transculturation (New York: 1992). Pratt defines contact zones as "social spaces where disparate cultures meet, clash and grapple with each other, often in highly asymmetrical relations of domination and subordination", Pratt, Imperial Eyes, 4.

32 Madame de Chénier, Lettres, 135. "qu'on voit danser encore aujourd'hui a Smyrne et dans l'Asie Mineure, où le gout des danses lascives subsiste toujours. Ils prennent plaisir de faire exécuter devant eux ces danses lascives et voluptueuses". (My own translation). 
The chapter on music in Il costume antico e moderno also comments on the mixing of ethnicities and religious minorities during private dancing. In spite of prohibitions, Ottomans love music as part of a cultural tradition emanating from Persia. In private gatherings, "Eight or ten players join and they are Muslims, Christians and Jews. They all bring their different instruments in the homes of those who invite them, while the Muslims listen attentively with their tobacco and opium pipes and coffee. They are so taken by the music, that they look ecstatic and on the point of fainting." ${ }^{33}$ At the end of a long digression on music, melody, and musical notes, the text refers to the "author of the work on costumes, customs etc. of the Ottomans" as its main source.

It is difficult to find a copy of the three extraordinary volumes of Ignatius Mouradgea d'Ohsson's Tableau général de l'Empire Ottoman, a rare elephant folio edition printed in Paris by the great Didot. The first volume was published in 1787 , the second, in 1790 , while the third was edited by his son in 1820 after Mouradgea d'Ohsson's death. A copy of the three volumes, bound in red Morocco leather with golden inserts, is in the Biblioteca Braidense in Milan where Ferrario spent most of his life. Mouradgea d'Ohsson's Tableau général is the main textual and only visual source for the chapters on the private and civic customs of the Ottomans in the 18th century in Ferrario's volume on the Ottoman Empire.

Born to a French mother and a Catholic Armenian father, Ignatius Mouradgea followed his father into the same profession, working as an Ottoman dragoman (interpreter) in the service of the Swedish consul in Constantinople. ${ }^{34}$ In this cosmopolitan milieu, the Mouradgeas, father and son, were cultural mediators, having a good knowledge of languages and being well-integrated in the court hierarchy and political networks of the Empire. Ignatius added the name d'Ohsson in 1787 when the king of Sweden, Gustave III, gave him noble status as reward for his services to the Crown. In 1784, he left for Paris to publish his outstanding work. The publication of the first two volumes must have been the editorial event of the day: it was printed by Pierre Francois Didot "the younger", a central figure of the luxury book trade in Paris who was famous for the beautiful typography of his books. A subscription aimed at an aristocratic

\footnotetext{
33 Ferrario, Impero Ottomano, 373.

34 Elisabeth A. Fraser, "Dressing Turks in the French Manner'. Mouradgea d'Ohsson's Panorama of the Ottoman Empire", Ars Orientalis 39 (2010), 199-229; Carter Findley, "Writer and Subject, Self and Other: Mouradgea d'Ohsson and his Tableau général de l'Empire Othoman", in Sture Theolin et al., The Torch of the Empire: Ignatius Mouradgea d'Ohsson and the Tableau général de l'Empire Othoman in the Eighteenth Century (Istanbul: 2002), 27-28.
} 
readership financed a deluxe elephant folio edition, illustrated with 233 engravings, 41 of which are full-page or double-page fold-outs. A team of at least 28 artists (painters, designers and engravers) produced most of the engravings under the direction of Charles Nicolas Cochin (1715-1791), a major figure in the 18th-century art world in Paris. Recent research has shed light on the Ottoman and Persian sources of the Tableau and on the French adaptation of the paintings and drawings that Mouradgea brought with him from Constantinople. Sources indicate that he spent part of the time at the Armenian Catholic monastery of San Lazzaro in Venice and worked with Armenian collaborators there. ${ }^{35}$ Elisabeth Fraser writes that, by bringing together both Ottoman and French artists, the Tableau général is a product of "active agents consciously adopting cross-cultural modes, implicitly negotiating issues of legibility, significance, and acceptability into the bargain". ${ }^{36}$

\section{Connecting Texts, Tracing Images}

In the opening discourse to the reader, Mouradgea d'Ohsson presents his work, the difficulties he had to face, and sketches a short biography: "I was born and grew up in Constantinople, and during my entire life I was employed in the service of a Court intimately connected to the Sublime Porte. More than anybody else I had the means to overcome all difficulties and to accomplish the task that I now decided to complete." His Tableau is based on Ottoman sources: national historians and the "Annals of the monarchy" of which he had a translation made. He accomplished his long research of the original codes of Islam with the "help of a very learned theologian and jurist both of whom enjoy a high reputation in the Empire". Eminent state officials, with whom he had personal ties, also assisted by giving him extracts of their own registers, thus enabling him to analyze, in detail, the structure of the Ottoman state. ${ }^{37}$ From the officials of the palace, he obtained information about the serail, the sultan, and his household, while the slaves in the serail supplied details about

35 Carter Findley, "Mouradgea d'Ohsson (1740-1807): Liminality and Cosmopolitanism in the Author of the Tableau général de l'Empire Othoman" in Turkish Studies Association Bulletin, 22, 1 (Spring 1998), 21-35.

36 Fraser, "Dressing Turks in the French Manner", 200.

37 Ignatius Mouradgea d'Ohsson, Tableau général de l'Empire Ottoman (Paris: 1787), v-VIII. Né à Constantinople, élevé dans le pays meme, et attaché toute ma vie au service d'une Cour liée avec la Porte par des relations intimes, j'ai eu plus que personne les moyens de vaincre ces difficultés, et de remplir la tache que je m'impose aujourd'hui. 
the sultanas, cadinns, and the imperial harem. He also informs the reader that many of them were freed after several years of service and married to court officials. His direct contact with these officials and with Christian women allowed him to correct the false opinions and inaccurate ideas he himself held. ${ }^{38}$

The work is divided into two parts: the first focuses on Muslim jurisprudence and the second details the history of the Ottoman Empire, which d'Ohsson never completed. He died in 1807 , after the publication of the first two volumes of his monumental work, each of which was over 300 pages long. In 1820, his son edited the third 50o-page volume on civil and penal law.

Although they include many prints of men's and women's civil, military, and court costumes, Mouradgea d'Ohsson's volumes do not resemble illustrated travelogues. The lengthy presentation of Islamic law is interspersed with digressions on morality, social practices, and vivid descriptions of Ottoman society from his own experience. Surprisingly, scholars have ignored this ethnographic aspect that is central to Il costume antico e moderno. To date, there is no knowledge of an Italian translation of the Tableau, and only partial editions in German, Russian, Swedish, and English, the latter being published in Philadelphia in 1788 .

In the second volume of Mouradgea d'Ohsson's Tableau général, the section on morality comprises two books: the first entitled 'Food' (de la nourriture) and the second, 'Dress' (du vetement). They discuss, respectively, pure and impure meats, forbidden and legal drinks, opium, coffee, tobacco and perfume; and dress, sumptuary norms on clothing and bodies, interior decoration, styles of clothing, colours, and carriages. Ferrario's text draws extensively from Livre One and Livre Two and quotes passages word by word, as shown by the descriptions of the different uses of Kashmir shawls and of dancing in Greek homes. ${ }^{39}$ Il costume antico e moderno also repeats the sections about shoes, the long digression on turbans, and the changing styles and decorations, as well as the sections about jewellery, interior decoration, baths, heating, carriages and servants.

However, some details are more abundant in Mouradgea d'Ohsson's narrative, which insists on the cosmopolitan dimension of the "immense" city of Constantinople that "mixes foreigners of different nations with the local inhabitants, Muslim and Christian, offering the most striking diversity of costumes and languages, and infinite nuances of customs and practices". ${ }^{40}$ An

\footnotetext{
38 Mouradgea d'Ohsson, Tableau général, IX-X.

39 Mouradgea d'Ohsson, Tableau général, 2, livre II: 140; Tableau général, 2, Code religieux, 428-29.

40 Mouradgea d'Ohsson, Tableau général, 2, Code religieux, 429.
} 
Armenian Catholic close to government circles, he emphasizes the leading role of Christian minorities in promoting gatherings in the European style, where families of the elite and officers of the court transgress religious norms and interact with one another:

families of a certain standing enjoy social gatherings at home. Many families live completely in the European way: their beds, their tables, the coming together of young men and women, games, and all that concerns civil life, stands in stark contrast to the way of living of the dominant nation. Those who have good connections to the young officers at court can easily invite them to their parties, at night and incognito, and this is when Muslims, freed of their prejudices and protected by their discreet hosts, totally yield to the pleasures of life. They drink wine; they cheer and sing at the table, forget the utterly severe Muslim mores, and get closer to the habits of Christians. In this pleasant forgetfulness, they sometimes allow themselves to dance the Georgina, a grotesque dance where people play the pantomime, with gestures, faces, ridiculous attitudes. They move their tongue, eyes, head, feet and hands as if they were separate parts of their body. ${ }^{41}$

As Elisabeth Fraser has highlighted, these comments are not part of an orientalizing attitude. On the contrary, Mouradgea d'Ohsson's Tableau aims to present Ottoman society in ways that enhance its modesty, industriousness, tolerance and lack of ostentation, eschewing the stereotypes that western travellers generally attributed to the inhabitants of this "non-communicative" empire. "Religious prejudices have constructed a barrier between the Empire and Europe", he writes, and these "phantoms" diffused by many books, have been mistaken for the real customs, habits, religion and law of the Ottomans. ${ }^{42}$ Reforms in education, regular diplomatic contacts with the West, and "a few young Muslims of good family", trained in Europe to become the new cosmopolitan ruling-elite, would transform "letters and public administration". These are his concluding remarks. An enlightened intellectual, he relies on an enlightened sultan to modernize Ottoman society from above.

Elisabeth Fraser defined the Tableau as a "self-conscious, autoethnographic defense of the Ottomans" 43 which offers a new perspective on the relationship between the French and the Ottomans. The illustrations that constitute

\footnotetext{
41 Mouradgea d'Ohsson, Code religieux, 433-434 (All English translations are mine).

42 Mouradgea d'Ohsson, Tableau général, 1, Discours préliminaire, III.

43 Fraser, "Dressing Turks in the French Manner", 200.
} 
a very significant part of the volumes are of particular importance for this perspective. D'Ohsson insists that Ottoman painters produced all the images with great difficulty and in secrecy. Due to a long-standing iconoclastic tradition, there were no great artists, certainly none comparable to painters in Italy, France, or the Netherlands:

How could they advance in this sublime art in a nation that doesn't care about it, where there are no models and where even the Christians have no taste for paintings, nor the habit of getting portrayed and where Greek and Armenian painters have no other resources for their talent but painting holy images in churches or in private chapels? [...] It is useless to talk about Muslim painters: there are perhaps twenty in the whole Empire and they limit themselves to landscapes, maps, and drawings [...] some paint animals, but rarely human figures. ${ }^{44}$

Getting artists to work for him was extremely difficult and time-consuming: in order to draw, they had to work either on their own or in d'Ohsson's home, in silence and secrecy. They could draw the interiors of mosques, sepulchral chapels, libraries and the rooms of the divan thanks to the watchful protection of some officers in the court; for illustrations of the serail and the harem, he managed to employ the same artists who had decorated them and already had very precise designs of these spaces. "Extreme caution, lengthy and expensive procedures as well as painstaking research enabled us in over ten years of work to acquire this collection of paintings and drawings illustrating Ottoman history." ${ }^{\text {45 }}$

All the paintings were engraved in Paris, but Cochin, charged with the artistic direction of the edition, assessed the figures negatively as "too short, their heads too big, without taste, without effect, and with a disagreeable perspective". 46 Therefore, at great expense, he decided to transform the original Ottoman images, hiring a French painter to repaint some of them which were then redrawn for the French engraver. A long work of decoding and interpreting visual traditions, taking care "not to translate them into the French style", went into the making of the 233 black-and-white prints that retained some of their sober truthfulness.

44 Mouradgea d'Ohsson, 2, Code religieux, 456-458.
45 Mouradgea d'Ohsson, 2, Code religieux, 462-463.
46 Fraser, "Dressing Turks in the French Manner", 213. 
In $\mathrm{Il}$ costume antico e moderno, 85 illustrations were readapted from the Tableau général to the volume on the Ottoman Empire. ${ }^{47}$ Redrawn and printed in Paris, they had lost some of the original Ottoman traits and Ferrario's small team of artists readjusted a visual apparatus that had already gone through a westernizing process of translation. Vittorio and Francesco Raineri, Leone Giacomo Bussi, and Giacomo Gallina engraved the prints and coloured them by hand, at times using different layouts and making small changes on the page. These artists were active in Milan in the first quarter of the 19th century. The following figures show a small sample of illustrations from the two works which highlight this process of visual translation and hand-colouring of prints from the Tableau général to the Impero Ottomano in Il costume antico e moderno.

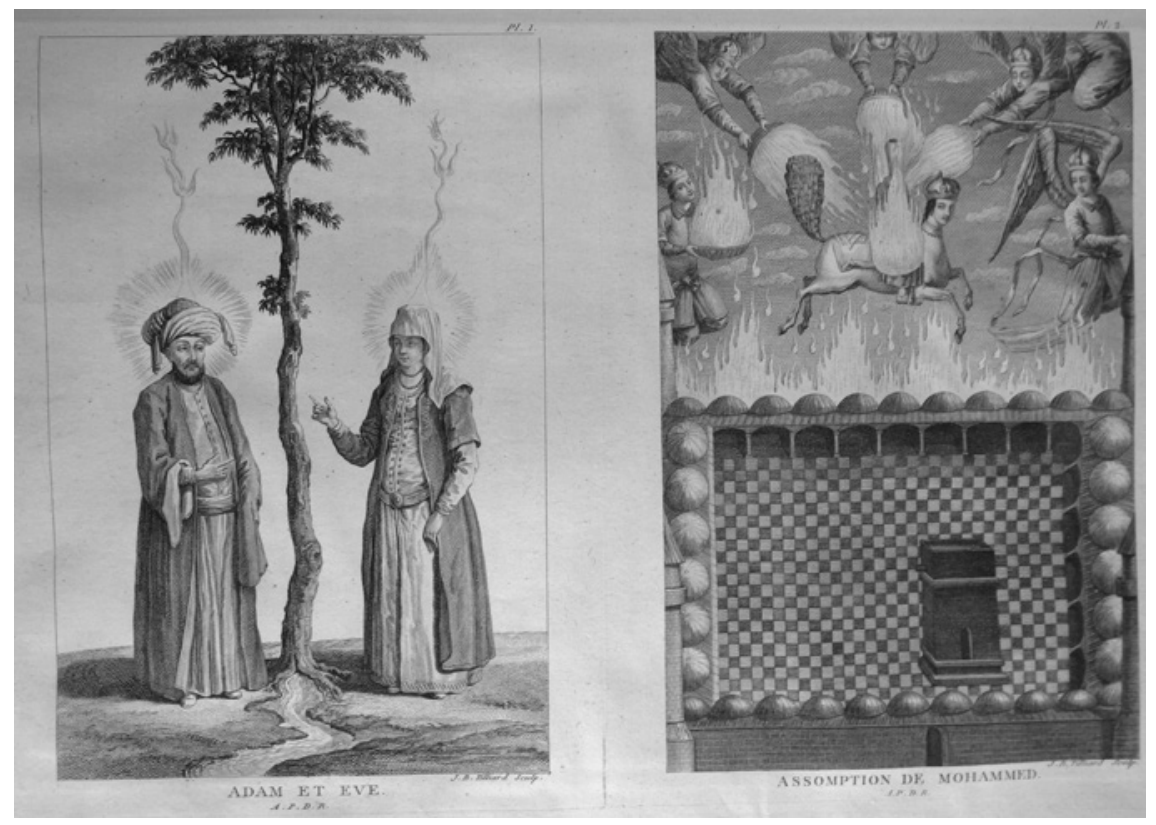

FIGURE 1.1 Mouradgea d'Ohsson, Tableau générale de l'Empire Othoman, Paris 1787, Tome 1, figs. 1-2 Adam et Eve; Assomption de Mohammed. COURTESY OF THE BIBLIOTECA BRAIDENSE. 


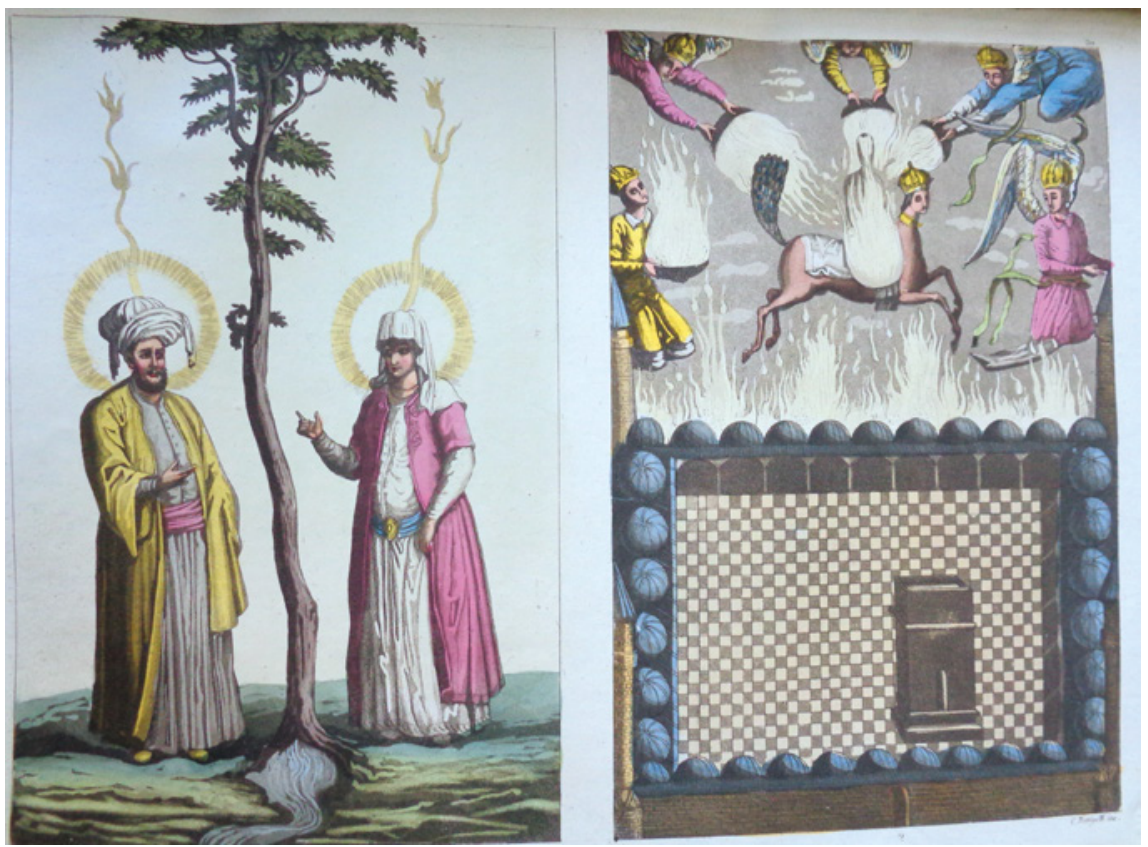

FIGURE 1.2 G. Ferrario, Il costume antico e moderno, vol. 4 (Milan 1827), fig. 30. COURTESY OF THE BIBLIOTECA BRAIDENSE.

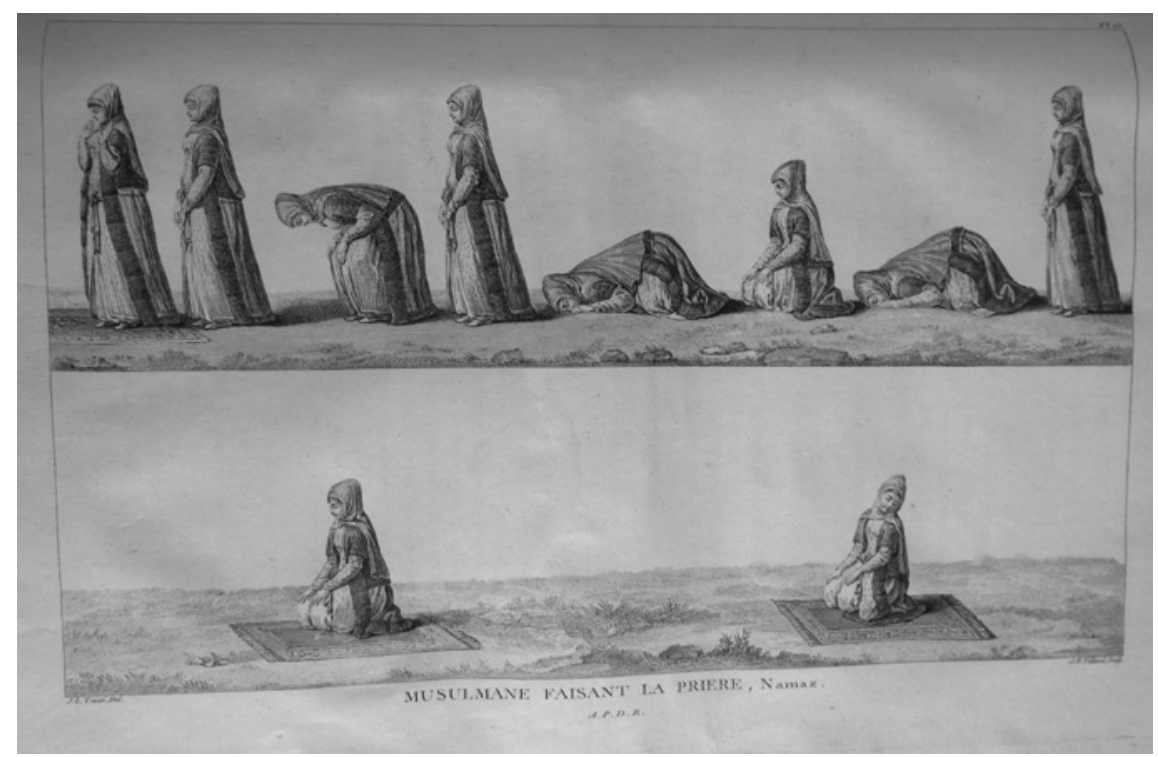

FIgURE 1.3 Mouradgea d'Ohsson, Tableau générale, Tome 1, Musulmane faisante la prière, fig. 15 .

COURTESY OF THE BIBLIOTECA BRAIDENSE. 


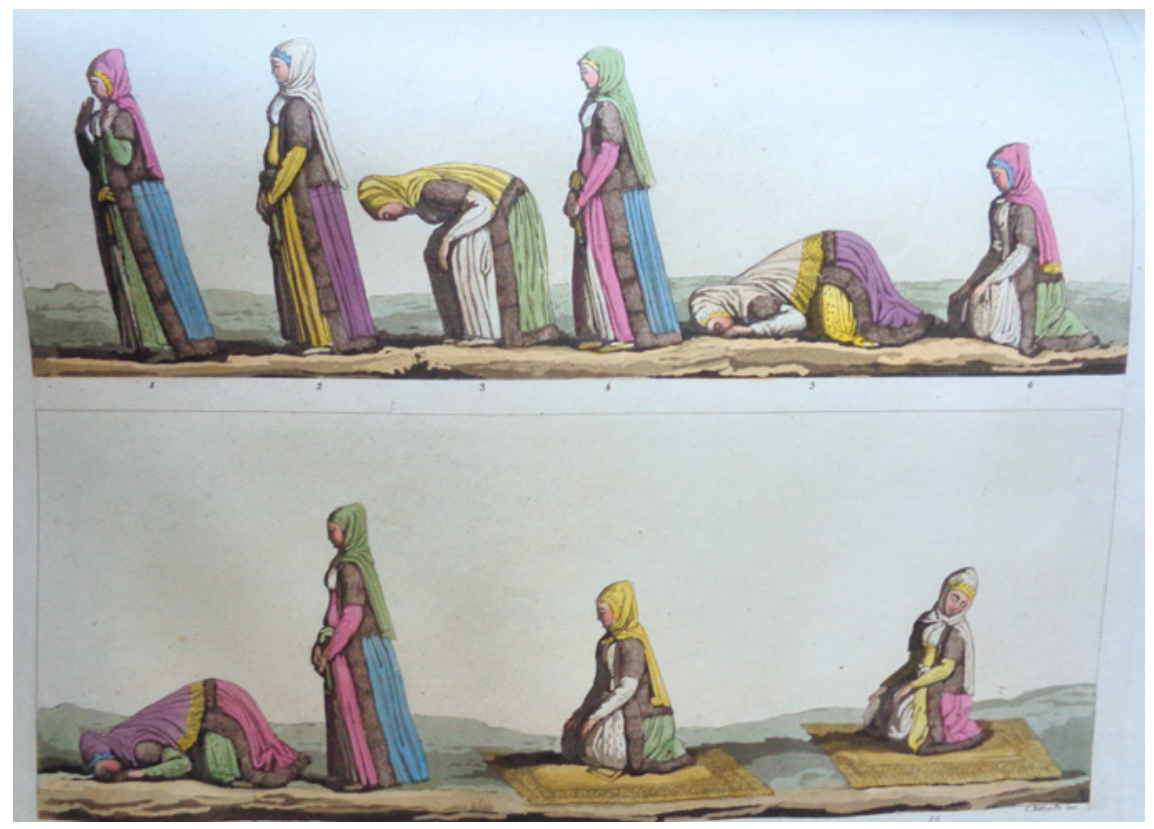

FIGURE 1.4 Ferrario, Il costume, vol. 4, fig. 35 . COURTESY OF THE BIBLIOTECA BRAIDENSE.

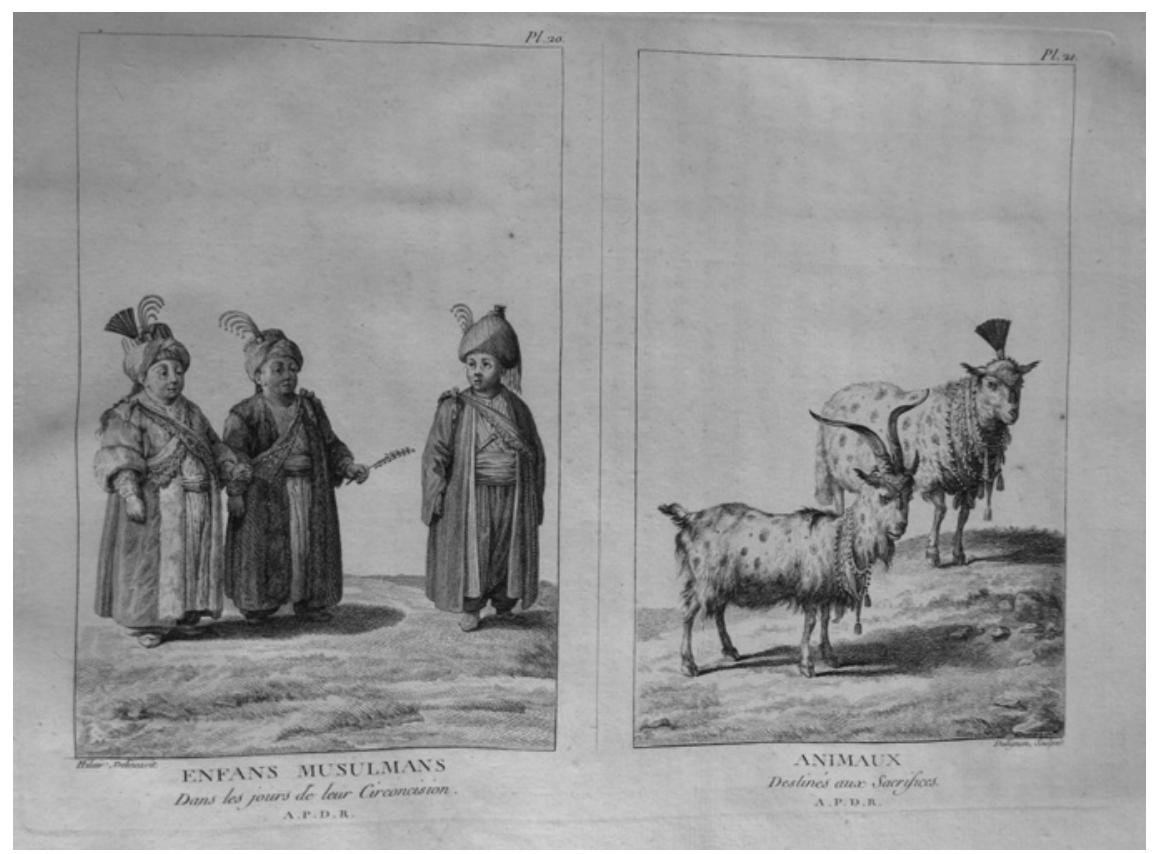

FIGURE 1.5 Mouradgea d'Ohsson, Tableau général, tome 1, Enfans Musulmans dans le jour de leur Circoncision; Animaux destinés aux sacrifice, figs. 20-21. COURTESY OF THE BIBLIOTECA BRAIDENSE. 


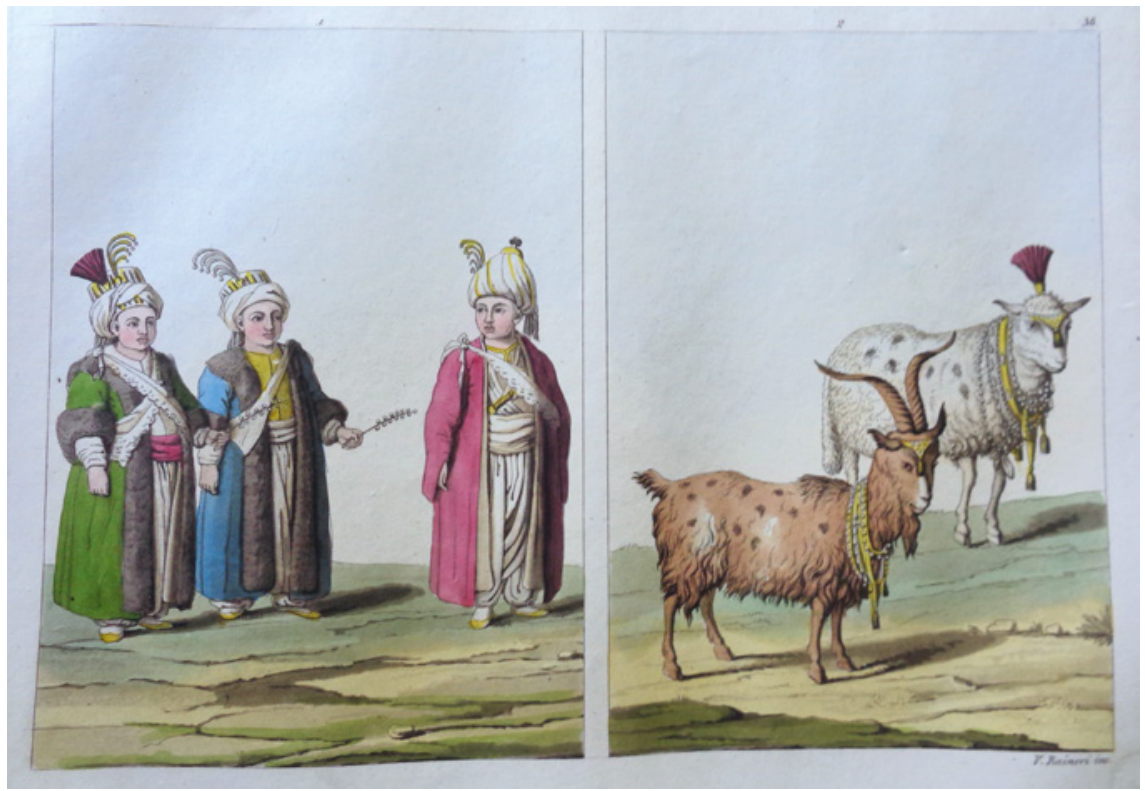

FIGURE 1.6 Ferrario, Il costume, vol. 4, fig. 36 .

COURTESY OF THE BIBLIOTECA BRAIDENSE.

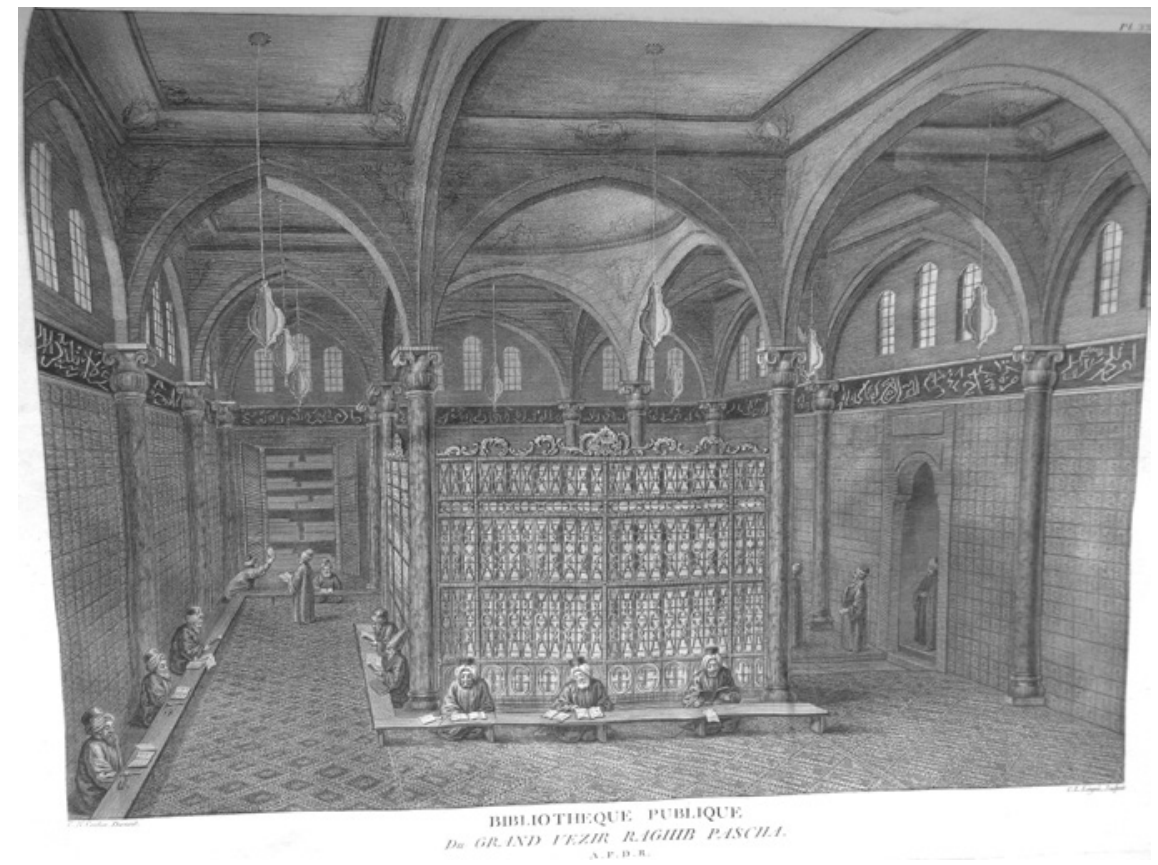

FIGURE 1.7 Mouradgea d'Ohsson, Tableau général, tome 1, Fig. 33, Bibliothèque publique. COURTESY OF THE BIBLIOTECA BRAIDENSE. 


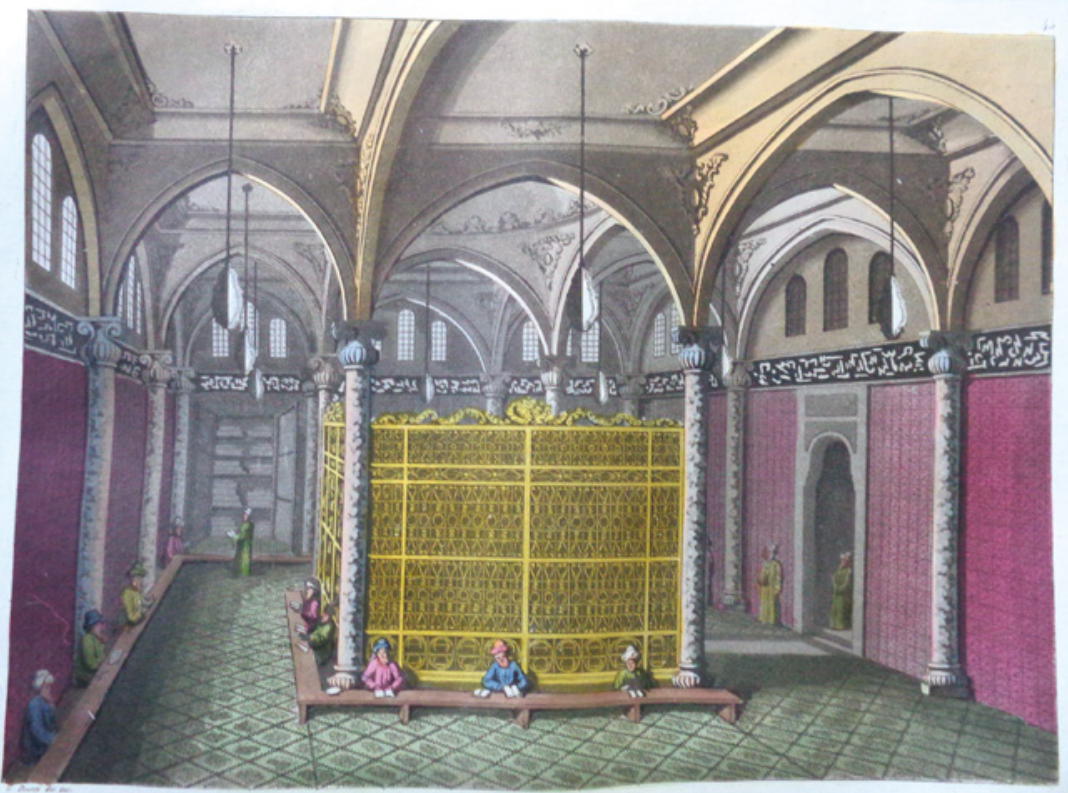

FIGURE 1.8 Ferrario, Il costume, vol. 4, tav. 45.

COURTESY OF THE BIBLIOTECA BRAIDENSE.

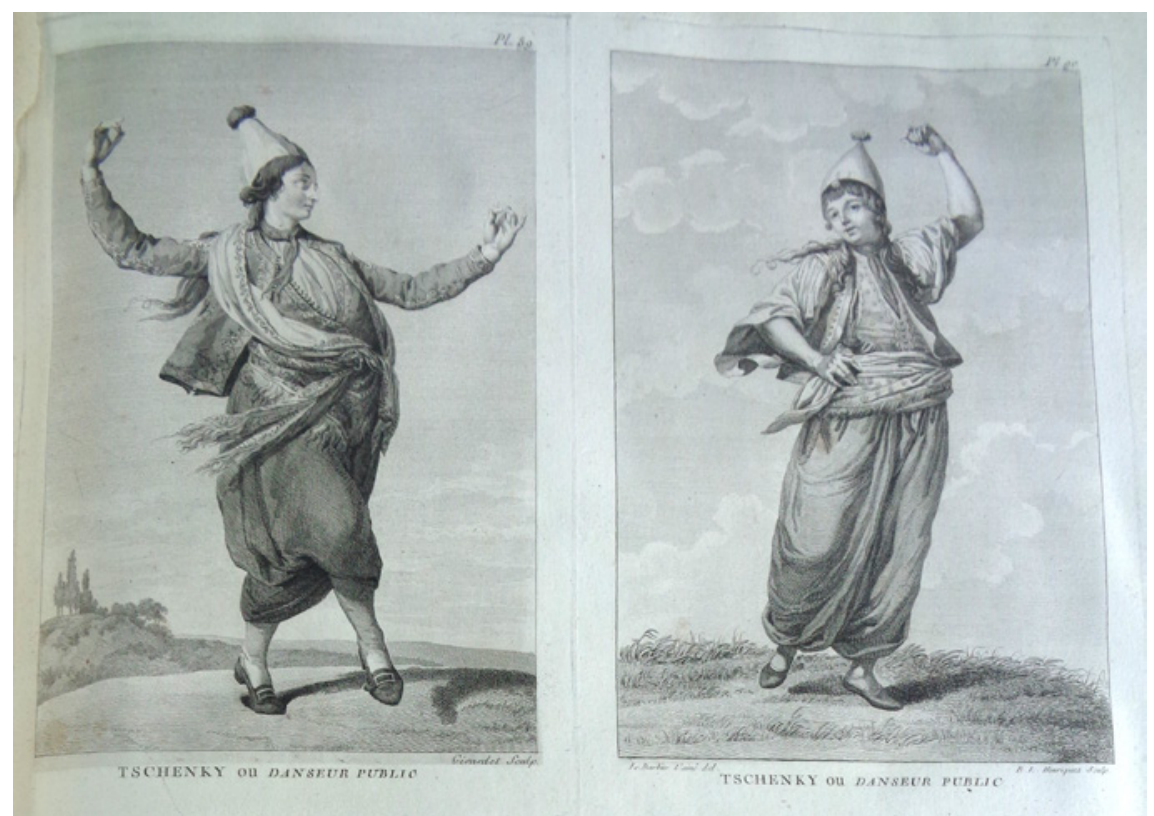

FIGURE 1.9 Mouradgea d'Ohsson, Tableau general (Paris, 179o) tome 2, figs. 89-9o Danseur publique, Danseuse publique.

COURTESY OF THE BIBLIOTECA BRAIDENSE. 


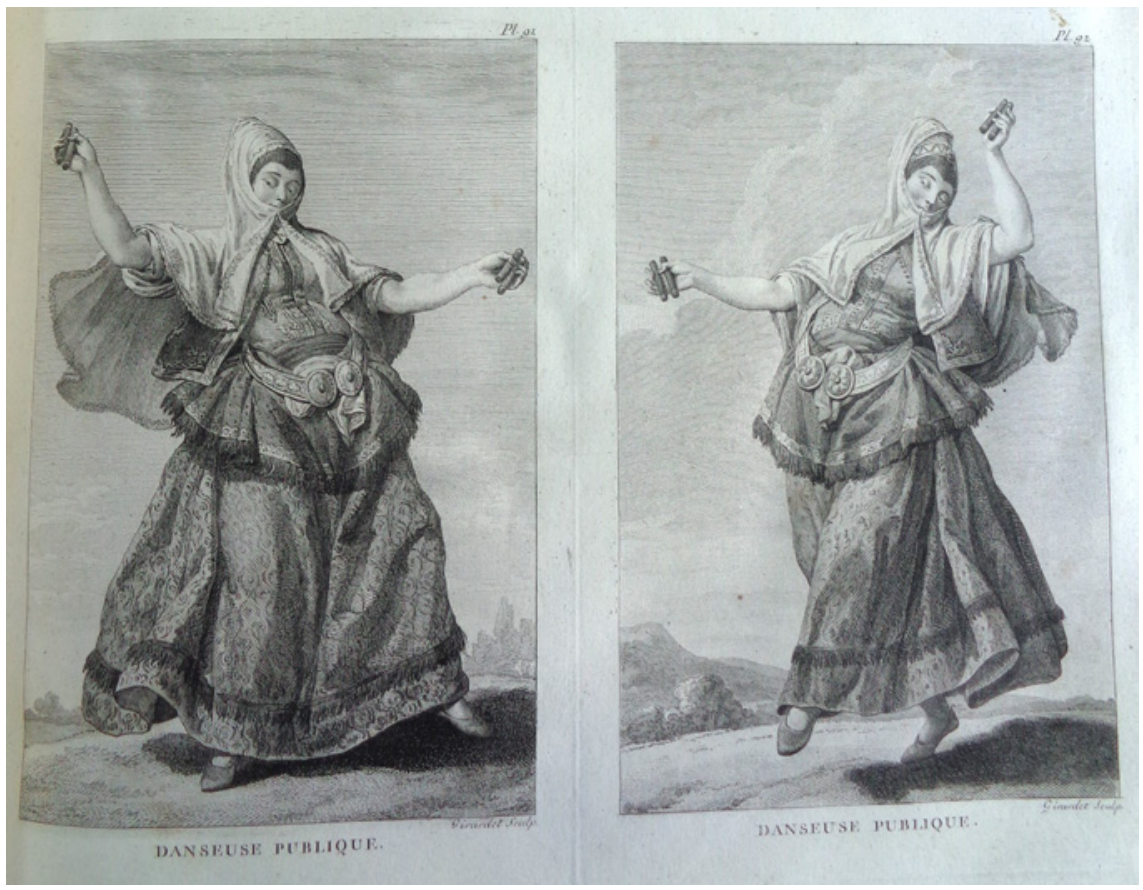

FIGURE 1.10 Mouradgea d'Ohsson, Tableau général, tome 2, Figs. 91-92, Tschenky, ou danseur publique.

COURTESY OF THE BIBLIOTECA BRAIDENSE.

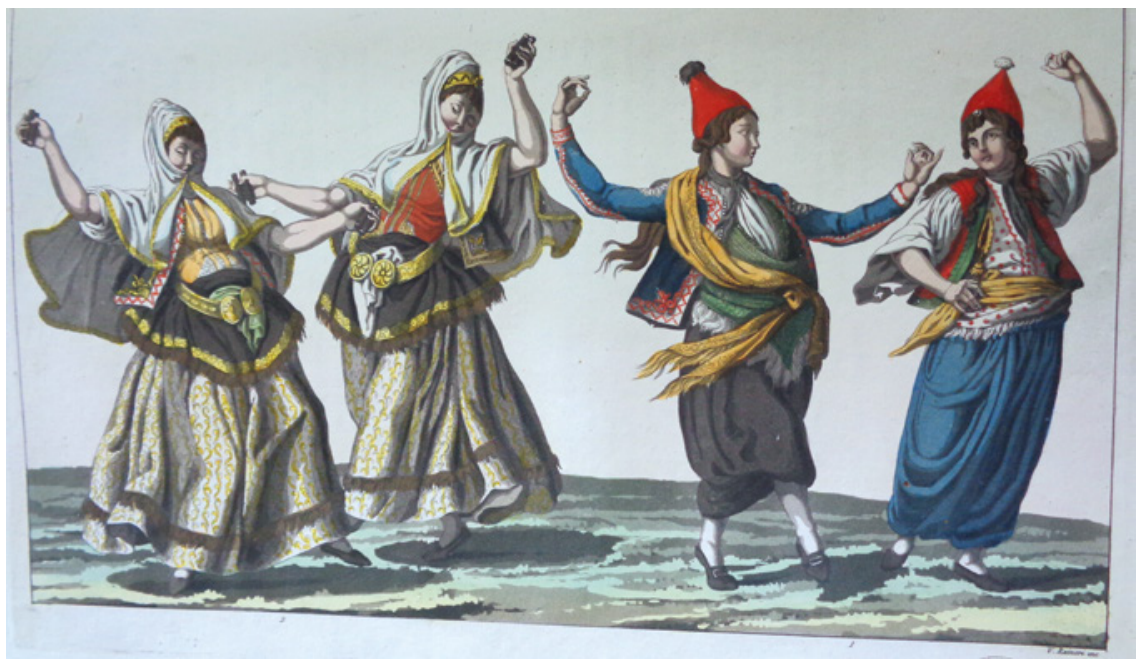

FIGURE $1.11 \quad$ Ferrario, Il costume, vol. 4, fig. 62.

COURTESY OF THE BIBLIOTECA BRAIDENSE. 


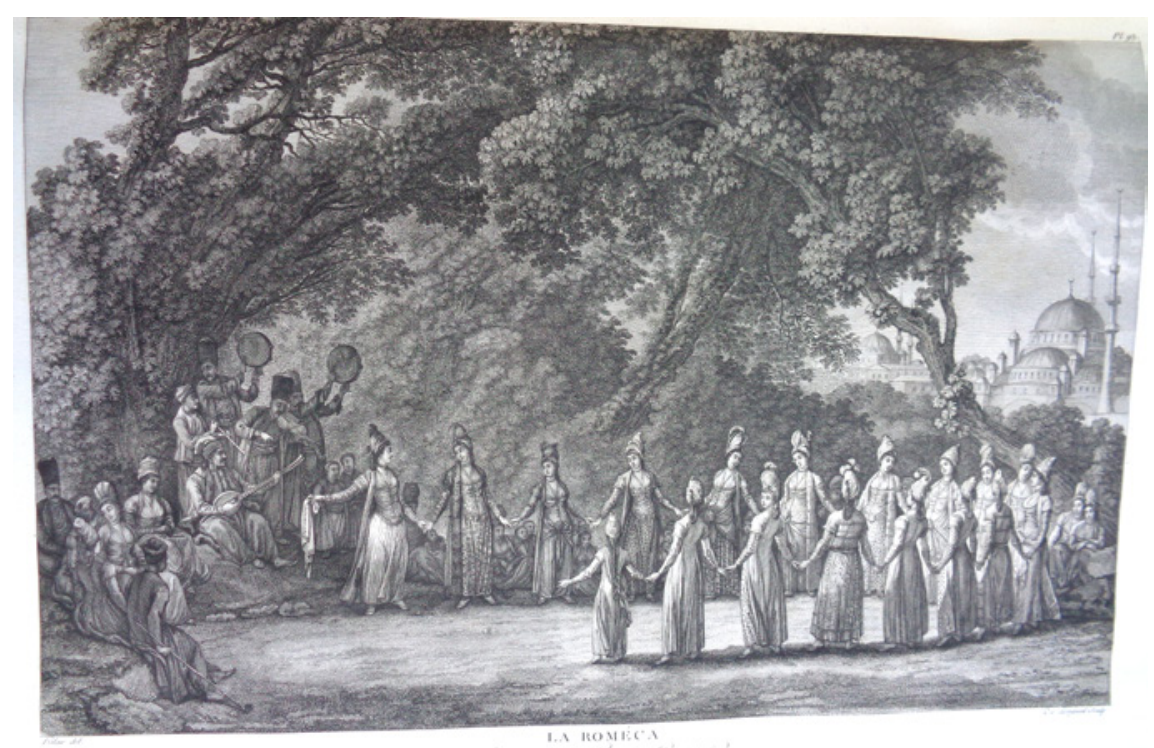

FIgURE 1.12 Mouradgea d'Ohsson, Tableau général, tome 2, fig. 93, La Romeca. Danse des femmes Grecques.

COURTESY OF THE BIBLIOTECA BRAIDENSE.

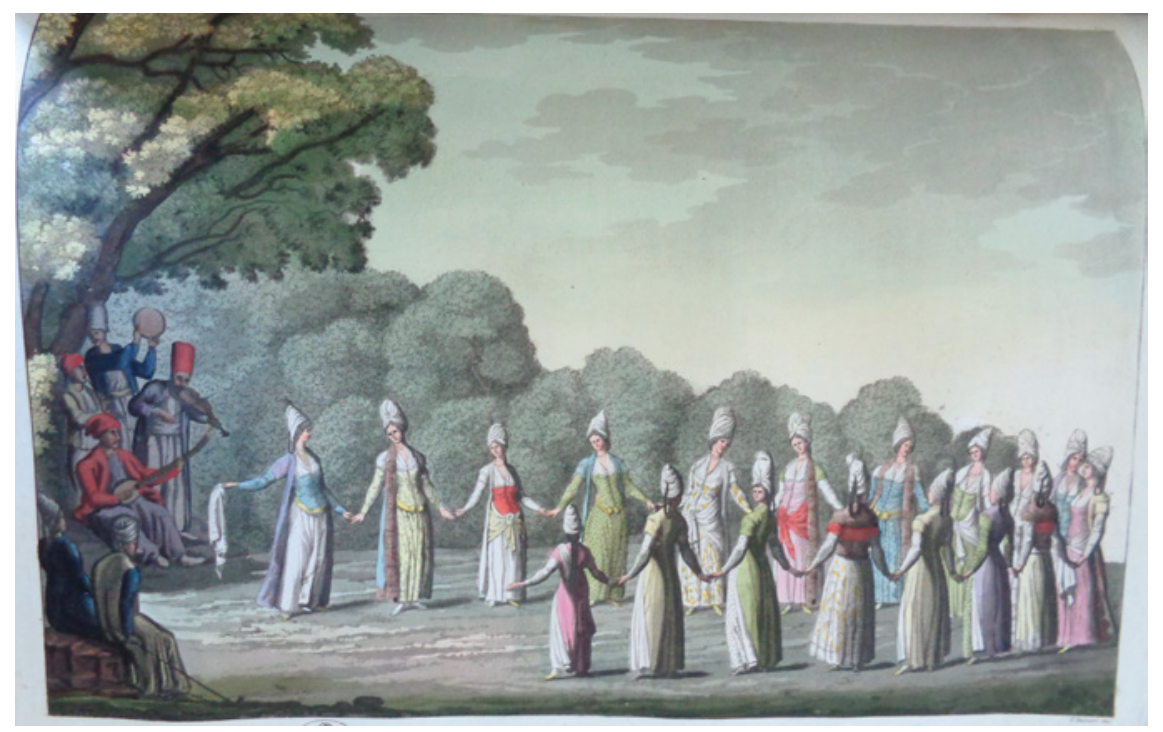

FIGURE $1.13 \quad$ Ferrario Il costume, fig. 63.

COURTESY OF THE BIBLIOTECA BRAIDENSE. 


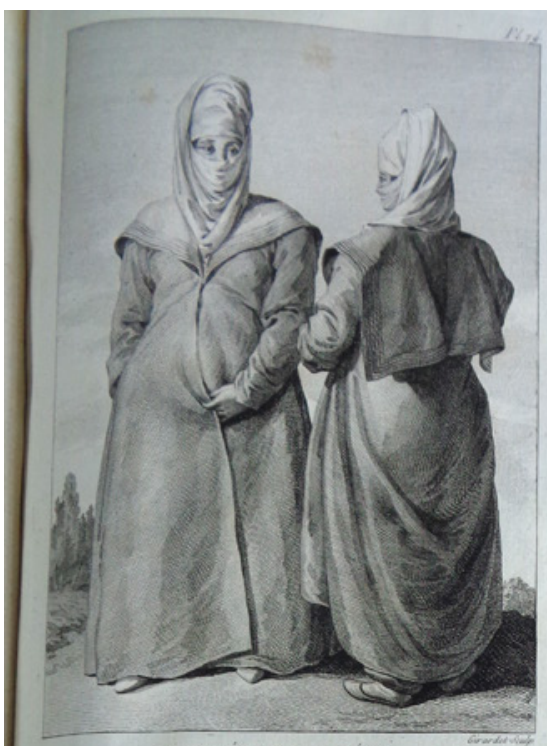

MAHOMÉTANES VOHÉES.

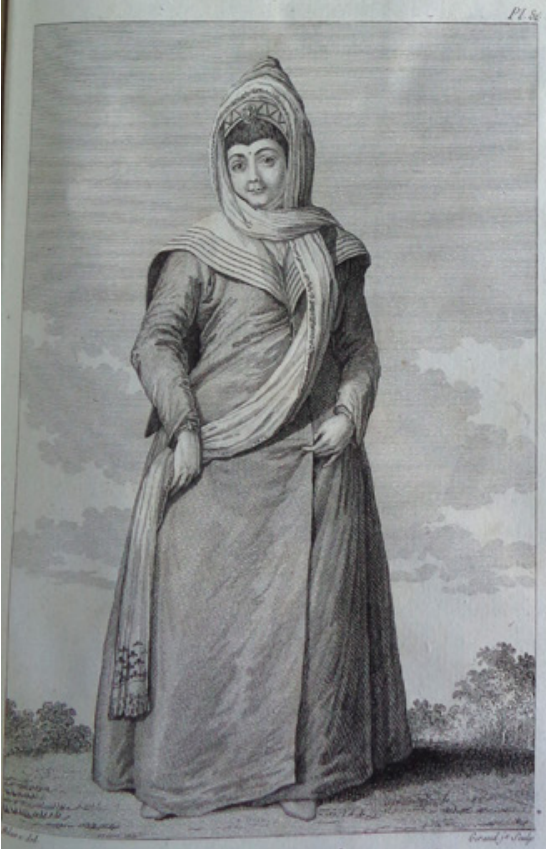

VUROPEENAE COUVRRT D'UN SCHAI.

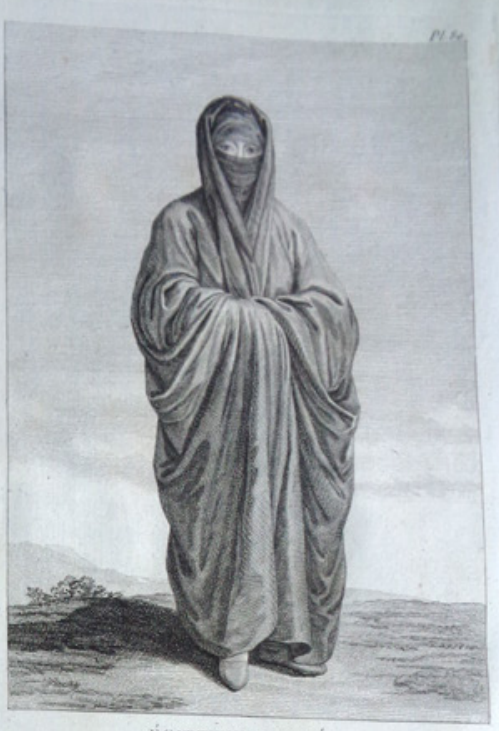

ÉGYTTENNY. YOLÉE.

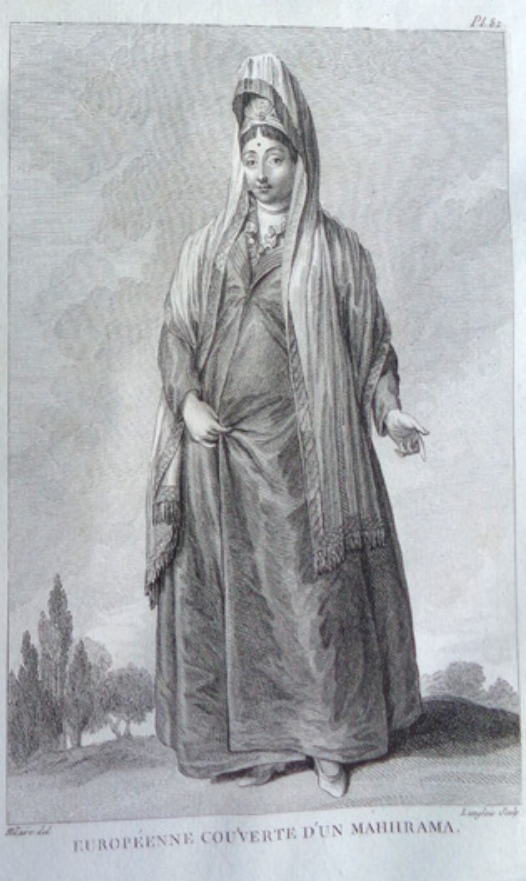

FIGURE 1.14

Mouradgea d'Ohsson, Tableau général, tome 2, figs. 79, 80, 81, 82 Mahometane voilée, Egyptienne voilée, Européenne couverte d'un schal, Européenne couverte d'un mahhrama.

COURTESY OF THE BIBLIOTECA BRAIDENSE. 


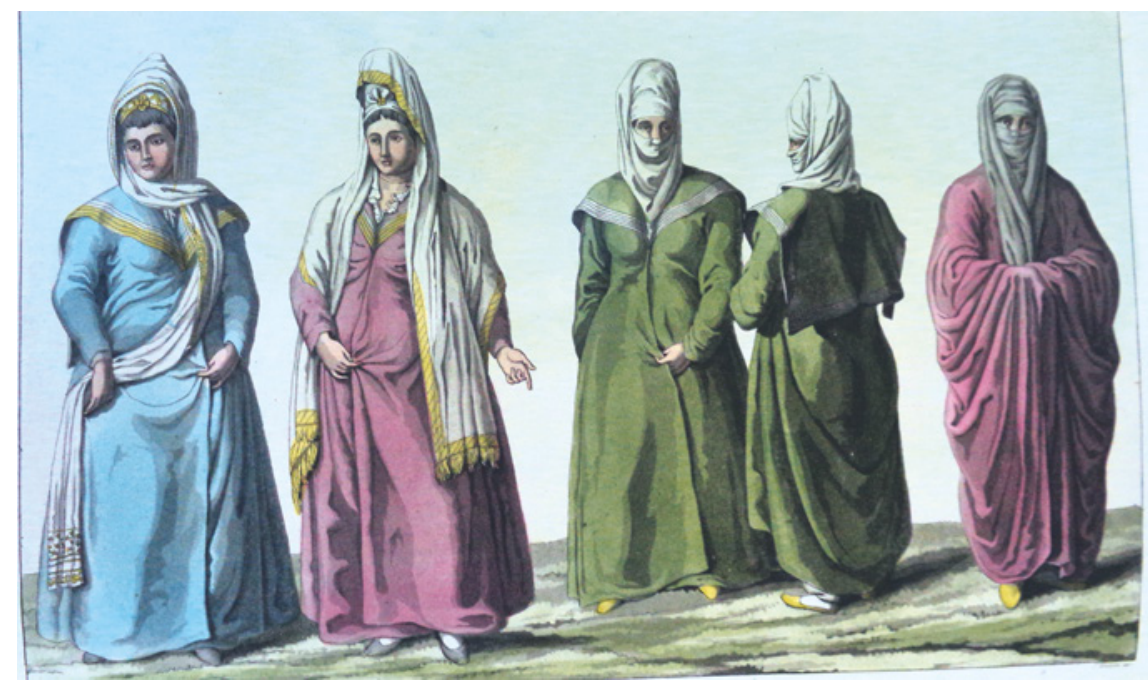

FIGURE 1.15 Ferrario, Il costume, vol. 4, tav. 60.

COURTESY OF THE BIBLIOTECA BRAIDENSE.

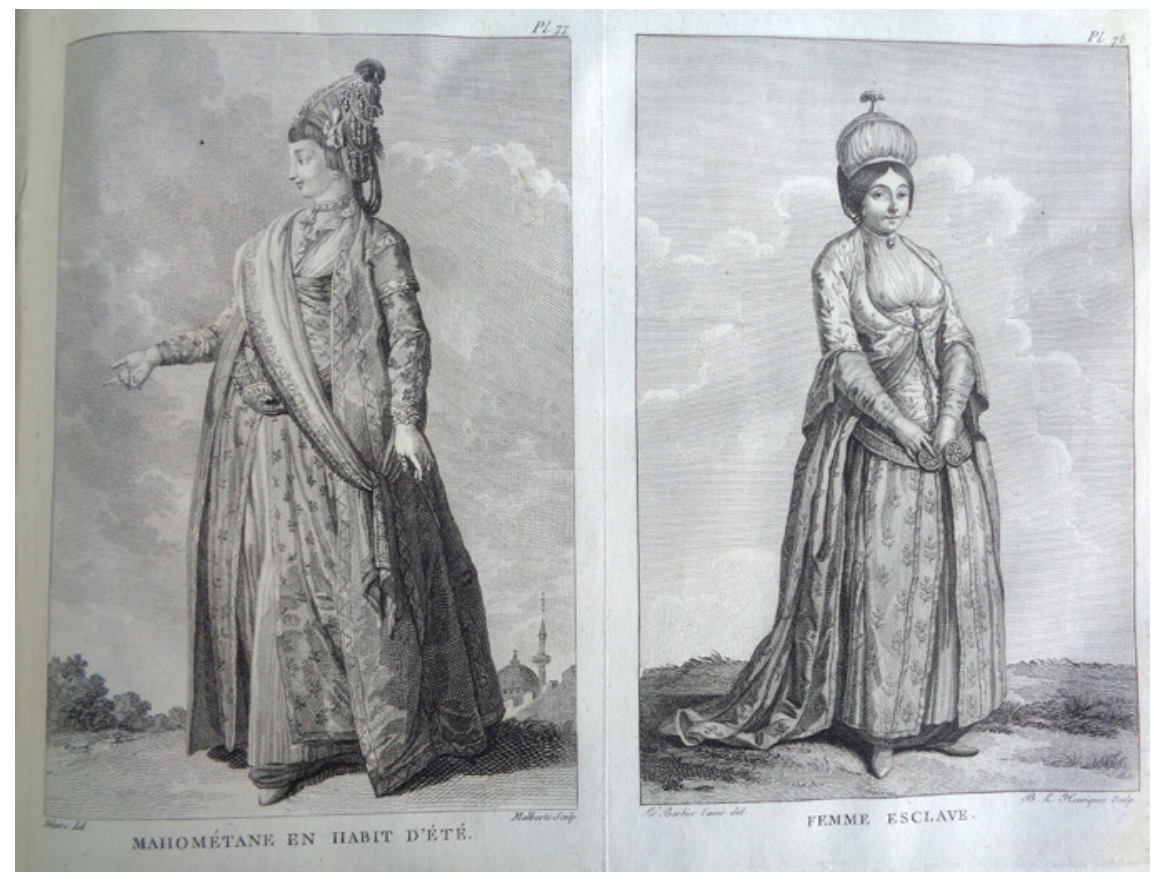

FIGURE 1.16 Mouradgea d'Ohsson, Mahometane en habit d'été. Femme esclave, Egyptienne voilée, Européenne couverte d'un schal, Eutopéenne couverte d'un mahhrama. 


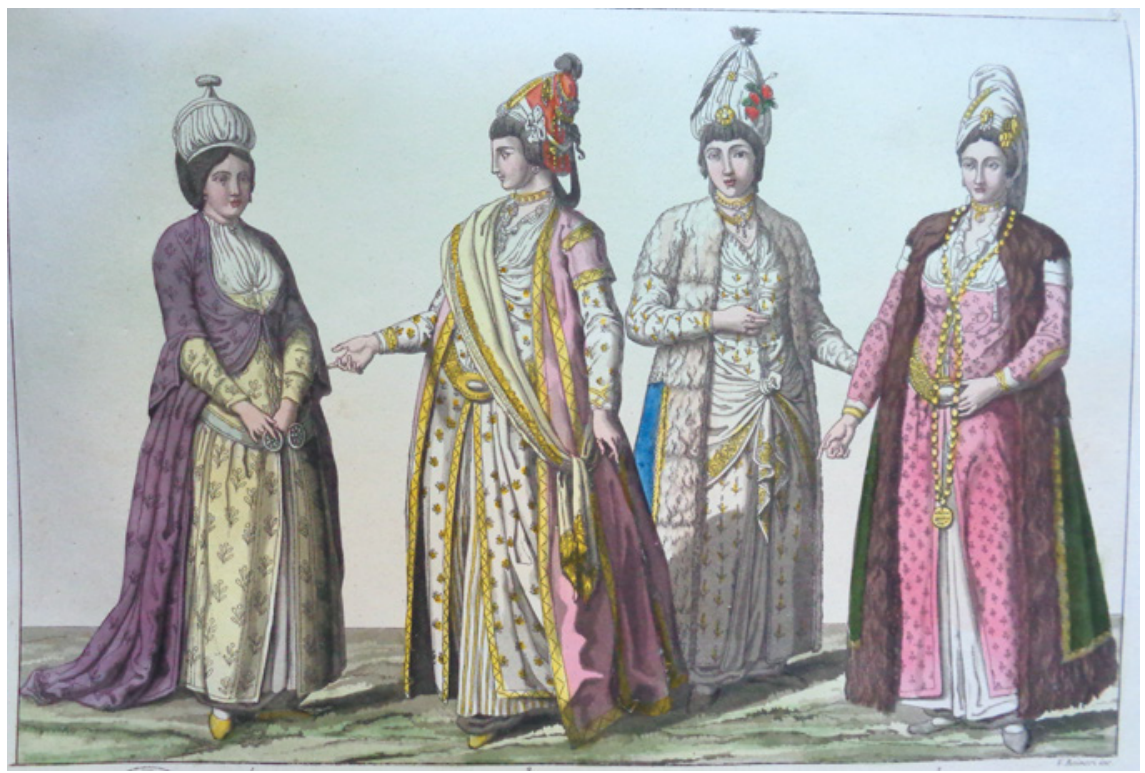

FIGURE 1.17 Ferrario tav. 60 .

In 1823, four years before the publication of Ferrario's volume, an octavo edition of the Storia dell'Impero Ottomano was printed in Milan. The author of the compendium, Giuseppe Compagnoni, ${ }^{48}$ was an ecclesiastic, polygraph, and jurist acting as a constitutional consultant to Napoleon in northern Italy. After a factual historical synthesis, the Storia sheds light on the private life of the Ottomans, repeating descriptions of food, clothing, and material culture in the same order as they appear in Mouradgea d'Ohsson's Livre One and Two of Book Two. Looking at this cheaper edition for middle-class readers with hardly any illustrations, the private life in the Ottoman Empire must not have appealed to the imagination of armchair travellers. Yet the fashion for Kashmir schals resonates again, mirroring the passion for Indian textiles all over Europe. ${ }^{49}$ Furs follow. The front page of Compagnoni's compendium lists Mouradgea d'Ohsson among the authors he borrowed from and traces the powerful image of the Prophet on the frontispiece of the Tableau général.

48 Dizionario Biografico degli Italiani, ad vocem.

49 Giuseppe Compagnoni, Storia dell'Impero Ottomano, 6 vols. (Milano: 1823), 119-120; The Tableau général was also printed in an octavo cheaper edition between 1788-1824. 


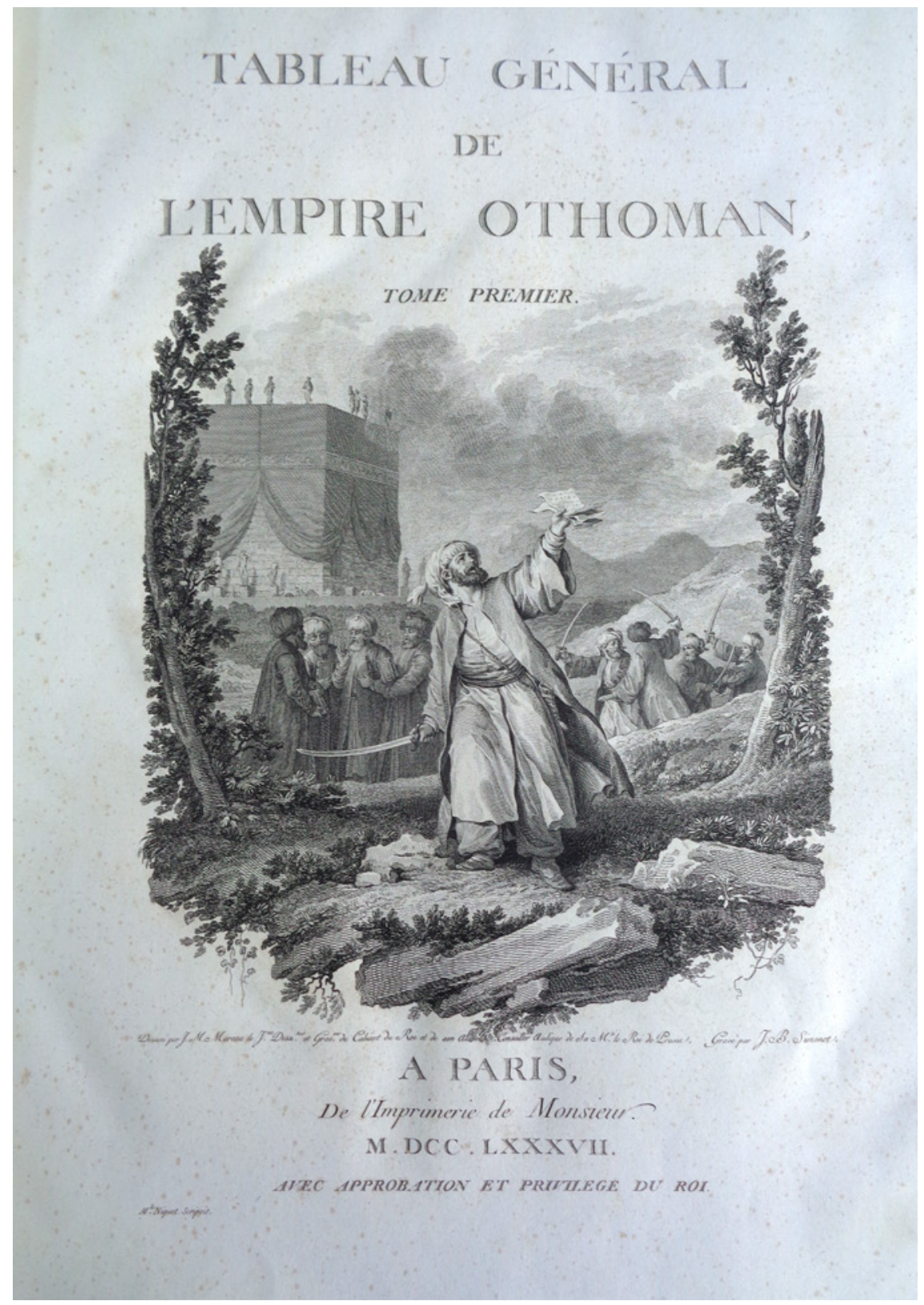

FIGURE 1.18

Mouradgea d'Ohsson, Frontispiece. 


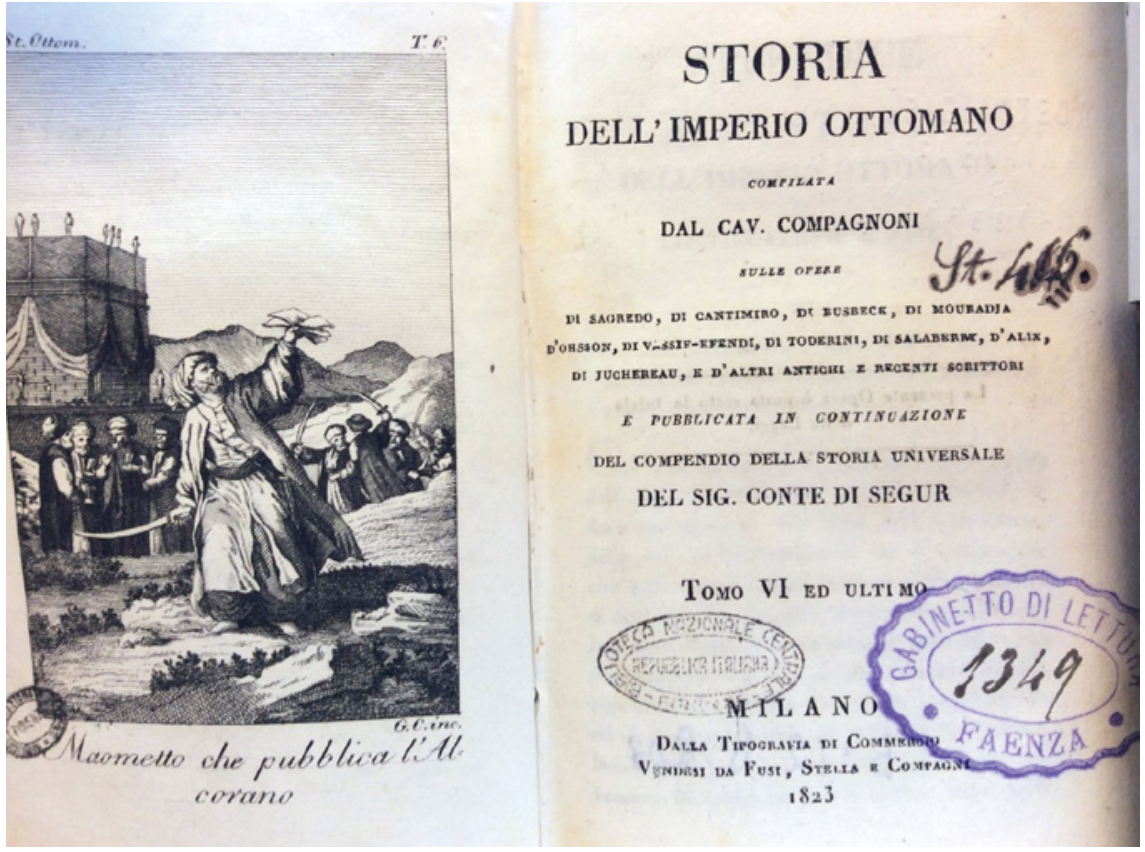

FIGURE 1.19 G. Compagnoni, Storia dell'Impero Ottomano, Frontispiece.

\section{Conclusion}

Descriptions of material culture open up a web of words and images, and outline the circulation of textual and visual knowledge across the Mediterranean, from the Ottoman Empire to France and Italy. By focusing on the work of Giulio Ferrario and Ignatius Mouradgea d'Ohsson, we showed the close connections between their writings and the unique ways in which the former-with his team of artists and engravers-borrowed from the latter.

Coming from a Christian minority, the dragoman Mouradgea d'Ohsson was a cultural broker, mediating between the Ottomans, French and Swedes. Due to financial difficulties and legal conflicts with collaborators and publishers, he spent his life in different court societies where he had good political connections. His view and criticism of the Empire come from an elitist standing and an insider's practice of government apparatuses. His profile and action fit well with the notion of a trans-imperial subject working inside institutions across multilingual and multiethnic geopolitical formations.

Giulio Ferrario, ecclesiastic, librarian, and printer, shares the same institutional profile. Living in Milan during the imperial transition between the 
French and the Habsburgs, Ferrario repeatedly acknowledges his position as a public intellectual and imperial subject trained in the Enlightenment tradition of reform, implemented by Joseph II in the kingdom of Lombardo Veneto. His volume on the Ottoman Empire introduces the anti-orientalist stance that Mouradgea d'Ohsson adopted in his Tableau général, going against the grain of conventional narratives. Adopting the Armenian's antiorientalism, did Ferrario mean to criticize the orientalizing gaze that the French and the Habsburgs projected onto their ruled subjects in the southern regions of Europe?

The stratified levels of meaning that this long process of translation implies, question analytic categories such as "transculturation", "contact zones" and cultural transfer. ${ }^{50}$ Even though Paris is the "centre," neither author fashions himself as a man on the margins. They are bi- or trilingual, publish in French and Italian, and constitute themselves and their work within a perspective that emphasizes interaction, copresence, and connectedness. Yet, in Mouradgea d'Ohsson's magnificent work, the Ottoman Empire shapes the relationship with the West by engaging with French aesthetic idioms and using Ottoman and Persian textual and visual sources to antagonize conventional orientalizing narratives. Translating, readjusting, and addressing Italian and European readers, Ferrario appropriates this complex work of cultural mediation. Il costume antico e moderno had seven editions in cheaper formats before 1840 while other compendiums with selective translations - such as Compagnoni's Storia dell'impero ottomano - circulated in different social milieus and in local contexts. They all contributed to the spreading of Mouradgea d'Ohsson's Tableau. However, in contrast to the French reception, which favoured the message that the Ottoman Empire, like Europe, had a coherent and intelligible legal and governmental system, ${ }^{51}$ in Italy, the dense and lively descriptions of etiquette, material culture, and sociality were selected, translated, and popularized beyond the elite readership who had subscribed to Il costume antico e moderno.

5o Pratt, Mary Louise, Imperial Eyes. Travel Writing and Transculturation (New York: 1992). Michael Werner and Bénédicte Zimmermann, "Histoire croisée and the Challenge of Reflexivity", History and Theory 45 (2006): 30-50; Jorg Feuchter, "Cultural Transfers in Dispute: an Introduction" in Jorg Feuchter (ed.), Cultural Transfers in Dispute: Representations in Asia, Europe and the Arab World since the Middle Ages (Frankfurt am Main: 2011); Anna Veronika Wendland, "Cultural Transfer", in Birgit Neumann und Ansgar Nunning (eds.), Travelling Concepts for the Study of Culture (Berlin: 2012), 45-66; on recent cross-cultural work see the special issue of Art History, volume 38, issue 4 Objects in Motion in the Early Modern World: http://onlinelibrary.wiley.com/doi/10.1111/ahis.2015.38 .issue-4/issuetoc September 2015.

51 Carter V. Findley, Mouradgea d'Ohsson, 43. 


\section{Bibliography}

Appadurai, Arjun (ed.), The Social Life of Things. Commodities in Cultural Perspective (Cambridge: 1986).

Art History, special issue on Objects in Motion in the Early Modern World: http://online library.wiley.com/doi/10.1111/ahis.2015.38.issue-4/issuetoc volume 38, 4, September 2015.

Berengo, Marino, Intellettuali e librai nella Milano della Restaurazione (Milan: 1980).

Berg, Maxine (ed.), Goods from the East (New York: 2015).

Berg, Maxine, "Luxury, the Luxury Trades, and the Roots of Industrial Growth: A Global Perspective", in Frank Trentmann (ed.), The Oxford Handbook of the History of Consumption, (www.oxfordhandbooks.com: 2012), 1-15.

Bleichmar, Daniela and Peter C. Mancall, (eds.), Collecting Across Cultures (Philadelphia: 2011).

Cassas, Louis-François, Voyage pittoresque de la Syrie et de l'Egypte (Paris: 1799).

Chénier, Madame de, Lettres grecques (Paris: 1879).

Choiseul-Gouffier de, Marie-Gabriel, Voyage pictoresque de la Grèce, 1-3 (Paris: 1782, 1809, 1822).

Compagnoni, Giuseppe, Storia dell'Impero Ottomano, 6 vols. (Milano: 1823).

De Vries, Jan, The Industrious Revolution (Cambridge: 2008).

De Vries, Jan, "Understanding Eurasian Trade in the Era of the Trading Companies", in Maxine Berg (ed.), Goods from the East (New York: 2015): 7-39.

Dizionario Biografico degli Italiani (Rome: 1960-).

Faroqhi, Suraiya, "Decline and Revivals in Textile Production" in Suraiya Faroqhi (ed.), The Cambridge History of Turkey, (Cambridge: 2016), 374 http://dx.doi.org/10.1017/ CHOL9780521620956.017.

Ferrario, Giulio, Il costume antico e moderno, o storia della milizia, della religione, delle arti, scienze ed usanze di tutti i popoli antichi e moderni, provata coi monumenti dell'antichità e rappresentata cogli analoghi disegni (Milan: 1817-1834).

Ferrario, Giulio, Il costume antico e moderno, o storia della milizia, della religione, delle arti, scienze ed usanze di tutti i popoli antichi e moderni, provata coi monumenti dell'antichità e rappresentata cogli analoghi disegni. Dell'Impero Ottomano. Degli Slavi moderni a cura di Carlo Magnetti, Europa, vol. 4 (Milan: 1827).

Feuchter, Jorg (ed.), Cultural Transfers in Dispute: Representations in Asia, Europe and the Arab World since the Middle Ages (Frankfurt am Main: 2011).

Findlen, Paula, Early Modern Things (London: 2013).

Findley, Carter, "Mouradgea d'Ohsson (1740-1807): Liminality and Cosmopolitanism in the Author of the 'Tableau général de l'Empire Othoman'” in Turkish Studies Association Bulletin, 22, 1 (Spring 1998), 21-35. 
Findley, Carter, "Writer and Subject, Self and Other: Mouradgea d'Ohsson and his Tableau général de l'Empire Othoman", in Sture Theolin et al., The Torch of the Empire: Ignatius Mouradgea d'Ohsson and the Tableau général de l'Empire Othoman in the Eighteenth Century (Istanbul: 2002).

Fraser, Elisabeth A., “'Dressing Turks in the French Manner'”. Mouradgea d'Ohsson's Panorama of the Ottoman Empire", in Ars Orientalis 39 (2010), 199-229.

Gommans, Jos, "For the Home and the Body: Dutch and Indian Ways of Early Modern Consumption", in Goods from the East, 331-349.

Grehan, James, Everyday Life and Consumer Culture in 18th-Century Damascus (London: 2007).

Hacquet de la Motte, Balthasar, L'Illyrie et la Dalmatie ou Moeurs, usages et costumes de leurs habitants (Paris: 1815).

Herbelot de Molainville, Barthélemy, Bibliothèque Orientale (Paris: 1777-1779).

Hirsch, Fred, The Social Limits to Growth (London: 1977).

Jardine, Lisa and Jerry Brotton, Global Interests, Renaissance Art Between East and West (London: 2000).

Leibsohn, Dana and Jeanette Favrot Peterson, (eds.), Seeing Across Cultures in the Early Modern World (London: 2012).

Lemire, Beverly and Giorgio Riello, "East \& West: Textiles and Fashion in Early Modern Europe", in Journal of Social History, 41 (2008): 887-916.

McNeil, Peter and Giorgio Riello, Luxury (Oxford: 2016).

Mouradgea d'Ohsson, Ignatius, Tableau général de l'Empire Ottoman (Paris: 1787).

Mukerji, Chandra, From Graven Images: Patterns of Modern Materialism (New York: 1983).

Muzzarelli, Maria Giuseppina and Carla Campanini (eds.), Disciplinare il lusso (Bologna: 2003).

Neumann Birgit and Ansgar Nunning, (eds.), Travelling Concepts for the Study of Culture (Berlin: 2012).

Pouqueville, Francois Charles, Voyage en Morée, à Constantinople et en Albanie 1798, 1799, 1800, 1801 (Paris: 1805).

Pratt, Mary Louise, Imperial Eyes. Travel Writing and Transculturation (New York: 1992).

Rampoldi, Giovan Battista, Annali Musulmani (Milan: 1822-26).

Rothman, Nathalie, Brokering Empire. Trans-Imperial Subjects between Venice and Istanbul (Ithaca: 2012).

Rublack, Ulinka, Dressing Up. Cultural Identity in Renaissance Europe (Oxford: 2010). Savage, Mike, "Status, Lifestyle and Taste", in The Oxford Handbook of the History of Consumption, (www.oxfordhandbooks.com: 2012), 1-13.

Theolin, Sture et al., The Torch of the Empire: Ignatius Mouradgea d'Ohsson and the Tableau général of the Ottoman Empire in the Eighteenth Century (Istanbul: 2002). 
Todorova, Maria, Imagining the Balkans (Oxford: 1997).

Wendland, Anna, Veronika, "Cultural Transfer", in Birgit Neumann and Ansgar Nunning (eds.), Travelling Concepts for the Study of Culture (Berlin: 2012), 45-66.

Werner, Michael and Bénédicte Zimmermann, "Histoire croisée and the Challenge of Reflexivity", in History and Theory 45 (2006): 30-50.

Wolff, Larry, Venice and the Slavs: The Discovery of Dalmatia in the Age of Enlightenment (Stanford: 2002). 